\title{
Characteristics of Heavy Storms and the Scaling Relation with Air Temperature by Event Process-Based Analysis in South China
}

\author{
Cuilin Pan ${ }^{1,2} \mathbb{D}^{-}$, Xianwei Wang $1,3,4,5, * \mathbb{C}$, Lin Liu ${ }^{6,7, *}$, Dashan Wang ${ }^{1}$ and Huabing Huang ${ }^{1,3,5}$ \\ 1 School of Geography and Planning, Sun Yat-sen University, Guangzhou 510275, China; \\ pancuil@mail2.sysu.edu.cn (C.P.); wangdash@mail2.sysu.edu.cn (D.W.); huanghb7@mail.sysu.edu.cn (H.H.) \\ 2 Department of Information Technology \& Automation, The Pearl River Hydraulic Research Institute, \\ Guangzhou 510611, China \\ 3 Guangdong Key Laboratory for Urbanization and Geo-simulation, Sun Yat-sen University, \\ Guangzhou 510275, China \\ 4 Southern Laboratory of Ocean Science and Engineering (Guangdong, Zhuhai), Zhuhai 519000, China \\ 5 Guangdong Provincial Engineering Research Center for Public Security and Disasters, Guangzhou 510275, \\ China \\ 6 Department of Geography, Guangzhou University, Guangzhou 510006, China \\ 7 Department of Geography, University of Cincinnati, Cincinnati, OH 45221, USA \\ * Correspondence: wangxw8@mail.sysu.edu.cn (X.W.); liulin2@mail.sysu.edu.cn (L.L.); \\ Tel.: +86-20-841-146-23 (X.W.)
}

Received: 29 December 2018; Accepted: 18 January 2019; Published: 22 January 2019

check for updates

\begin{abstract}
The negative scaling rate between precipitation extremes and the air temperature in tropic and subtropic regions is still a puzzling issue. This study investigates the scaling rate from two aspects, storm characteristics (types) and event process-based temperature variations. Heavy storms in South China are developed by different weather systems with unique meteorological characteristics each season, such as the warm-front storms (January), cold-front storms (April to mid-May), monsoon storms (late May to June), convective storms, and typhoon storms (July to September). This study analyzes the storm characteristics using the hourly rainfall data from 1990 to 2017; compares the storm hyetographs derived from the one-minute rainfall data during 2008-2017; and investigates the interactions between heavy storms and meteorological factors including air temperature, relative humidity, surface pressure, and wind speed at 42 weather stations in Guangzhou during 2015-2017. Most storms, except for typhoon and warm-front storms, had a short duration $(3 \mathrm{~h})$ and intense rates $(\sim 13 \mathrm{~mm} / \mathrm{h})$ in Guangzhou, South China. Convective storms were dominant $(50 \%)$ in occurrence and had the strongest intensity $(15.8 \mathrm{~mm} / \mathrm{h})$. Storms in urban areas had stronger interactions with meteorological factors and showed different hyetographs from suburban areas. Meteorological factors had larger variations with the storms that occurred in the day time than at night. The air temperature could rise $6{ }^{\circ} \mathrm{C}$ and drop $4{ }^{\circ} \mathrm{C}$ prior to and post-summer storms against the diurnal mean state. The 24-h mean air temperature prior to the storms produced more reliable scaling rates than the naturally daily mean air temperature. The precipitation extremes showed a peak-like scaling relation with the 24-h mean air temperature and had a break temperature of $28^{\circ} \mathrm{C}$. Below $28^{\circ} \mathrm{C}$, the relative humidity was $80 \%-100 \%$, and it showed a positive scaling rate. Above $28^{\circ} \mathrm{C}$, the negative scaling relation was likely caused by a lack of moisture in the atmosphere, where the relative humidity decreased with the air temperature increase.
\end{abstract}

Keywords: heavy storm; hyetograph; temperature; clausius-clapeyron scaling 


\section{Introduction}

Heavy storm rainfall is the driving force of urban pluvial flooding. Mega cities, especially in the developing countries, such as China and India, suffered frequent flooding disasters in recent years in the context of global warming and fast urbanization [1-3]. Urban pluvial flooding or waterlogging is a common problem in many mega cites of China, such as Nanjing, Wuhan, and Guangzhou [4]. Guangzhou faces severe challenges for its over-stressed storm water drainage systems due to the heavy tropical storms and rapid urbanization in the past 30 years [5]. The impervious urban areas have a complicated impact on local weather systems, resulting in the phenomena of a heat and rain island [6]. Numerical modeling studies found that the increase of urban areas would significantly intensify the local extreme rainfall $[1,7,8]$. Experimental observations reported that the precipitation down-wind of large cities could increase $5 \%-25 \%$ from the background values $[1,6]$. There are urgent needs to study and update the heavy rainfall characteristics for better storm water management and emergency response in the metropolitan areas of Guangzhou, South China.

Heavy storms in South China are developed by different weather systems each season. They have dynamically unique environment structures largely controlled by three-dimensional meteorological factors, such as air temperature, humidity, pressure, and wind speed and direction, leading to different storm types and forming mechanisms. Four types of warm season storms are reported in the literature $[9,10]$, that is, cold-front storms (April to mid-May), monsoon storms (late May to June), convective storms, and typhoon storms (July to September). Most warm season storms have a short duration and intense rates in Guangzhou, except for typhoon storms [5,11].

Heavy storms have complicated interactions with air temperature. The impact of air temperature on precipitation extremes have been extensively investigated after the pioneering work of Lenderink and van Meijgaard [12] in the Netherlands. The ideal gas law and Clausius-Clapeyron (CC) equation is the theoretical basis for such studies. The water-holding capacity of the atmosphere increases with the air temperature by about $7 \%{ }^{\circ} \mathrm{C}^{-1}$ globally for a given relative humidity, thus the precipitation extreme is proposed so as to scale with the precipitable water content in the atmosphere [12,13]. Many studies have investigated the scaling rate using numerical models and field observations at regional and global scales. Overall, five types of scaling rates between surface daily mean air temperature and precipitation extremes were reported, namely sub-CC $\left(\sim 3 \%{ }^{\circ} \mathrm{C}^{-1}\right)$, close-CC $\left(\sim 7 \%{ }^{\circ} \mathrm{C}^{-1}\right)$, super-CC $\left(\sim 14 \%{ }^{\circ} \mathrm{C}^{-1}\right)$, peak-like CC (positive and negative), and negative CC [14-17].

The apparent scaling rates are mostly affected by the regional climatic settings, namely air temperature variation ranges and available water vapor. Sub-CC, close-CC, and super-CC were reported in mid and high latitude regions with a daily mean air temperature below $\sim 20^{\circ} \mathrm{C}$, such as in the Netherlands [12], Germany [18], France [13], and Canada [16], and in the winter time of mid-latitude regions, such as the United States [14], southern Australia [19], and China [20]. Peak-like CC were reported in the mid latitude regions $\left(20-55^{\circ} \mathrm{N}\right.$ and $\left.20-55^{\circ} \mathrm{S}\right)$, with the upper range of daily mean temperature above $25^{\circ} \mathrm{C}[14,21,22]$, such as in Central Australia [19], South China [20], and Southern France [13]. The negative CC were reported in the tropic regions and the summer of the subtropical regions with a daily mean temperature above $25^{\circ} \mathrm{C}$ [14], such as in Brazil [15], Northern Australia [19,23], South China [20], and Hong Kong [24].

Other factors affecting the scaling rates include the available moisture source (humidity), percentiles, and durations used to quantify the precipitation extremes. Higher percentiles and a shorter duration display a better close-CC or supper-CC $[13,14,16]$. The negative part of the peak-like scaling was explained by the lack of a moisture source, such as in Southern France [13]. This was supported by the fact that there was a general decrease in the relative humidity with a temperature increase at most stations in Australia, which suggests that the precipitation extremes were not only associated with how much moisture the atmosphere can hold, but also with how much moisture was available in the first place $[15,19,23,25,26]$.

In summary, the current studies are mostly aimed at how global/regional warming intensifies the precipitation extremes conditional to the rainfall occurring with an available moisture source. 
The orographic and other meteorological factors influencing rainfall occurrence are also important in constraining the changes of the precipitation extremes. However, few studies investigate the feedback and interactions of precipitation extremes with air temperature and other meteorological factors prior to and after a storm, especially in the tropical and subtropical regions. The behavior and mechanisms of tropical and subtropical heavy storms are worthy of further investigations.

The primary objectives of this study are (1) to analyze the characteristics of the different types of heavy storms in the metropolitan areas of Guangzhou, South China (subtropical, $23^{\circ} \mathrm{N}$ ), and (2) to reveal the interactions of the heavy storms with air temperature and other meteorological factors, including relative humidity, surface pressure, and wind, using event process-based analysis.

\section{Study Area and Data}

\subsection{Study Area}

The City of Guangzhou is located in the upper Pearl River Delta in Southern China (Figure 1a). It has a sub-tropic climate controlled by the Indian summer monsoon and the South China Sea monsoon later in the year, with an annual mean air temperature of $22{ }^{\circ} \mathrm{C}$ and precipitation of $1700 \mathrm{~mm}[27,28]$. The warm and wet rainy season starts from April through to September, and falls over $80 \%$ of the annual precipitation [4,29]. The rainy season is usually divided into three periods [30]. From April to mid-May, rainfall is dominated by frontal systems, being affected by the large-scale cold air south down from the mid-latitudes and the southwest warm air along the west flank of the western North Pacific subtropical high [31]. From late May to June, after the summer monsoon onset over the South China Sea, the monsoonal rain band advances up to the Pearl River Delta areas (Guangzhou), and the rainfall mainly results from a southeasterly direction, which transports water vapor into Guangzhou [9,10,32]. From July to September, monsoon rainfall becomes relatively weakened, and convective thunderstorms and tropical cyclones contribute appreciably to the rainfall in Guangzhou $[33,34]$. The first two periods are also called the first rainy season, while the third period is called the second rainy season [11]. The warm season storms in Guangzhou can be classified into four classes, mostly based on the location of the subtropical high (i.e., the cold-front storms, monsoon storms, convective storms, and typhoon storms) [30].

At present, the administration area of Guangzhou is $7434 \mathrm{~km}^{2}$. It includes 11 districts-Yuexiu, Haizhu, Liwan, Tianhe, Baiyun, Huangpu, Huadu, Panyu, Nansha, Chonghua, and Zengcheng [5]. The metropolitan area has undergone fast urbanization during the past 30 years, and the built-up area ratio increased from 3\% to 24\% from 1990 to 2013, according to Landsat images [5]. There are 42 standard automatic weather stations in Guangzhou. These stations are divided into two groups of urban and suburban, so as to examine the generic characteristic of the meteorological factors and their variations with storms in this study (Figure 1b). In addition, six stations in the Tianhe (Site 2/rain gauge) and Panyu (Site 1, 3-6) Districts had a one-minute record of rainfall and water depth data, which were used to develop the rain hyetograph (Figure 1c).

\subsection{Rain Depth and Other Meteorological Data}

The 42 automatic weather stations contained data on the rainfall accumulation, air temperature, relative humidity, surface pressure, wind speed, and direction. All of the data were processed and archived in an hourly interval. Their precisions were $0.1 \mathrm{~mm}$ for precipitation, $0.1{ }^{\circ} \mathrm{C}$ for air temperature, $0.1 \%$ for relative humidity, $0.1 \mathrm{~m} / \mathrm{s}$ for wind speed data, and $1^{\circ}$ for wind direction. The data duration was 28 months, from July 2015 to October 2017. All of the climate data were validated by using quality control procedures [35-37].

Two sources of rainfall data from six automatic gauges were used to develop the storm hyetograph. The first one was from the national standard weather stations (Sites 1 and 2) of China, where the rainfall data were automatically recorded at one-minute intervals with a precision of $0.1 \mathrm{~mm}$ (Figure 1c). Site 2 is in the downtown area of the Tianhe District, Site 1 is in the suburban Panyu District, and both sites 
are $25 \mathrm{~km}$ apart. In addition, the processed hourly-interval rainfall data from 1990-2017 at Sites 1 and 2, and the hourly data at Sites 3-6 from 2014-2017, were used to analyze the storm features separately for the suburban and urban stations at the climatic time scale. Sites 3-6 were set up in the summer of 2014 at the Panyu District by our own research team. The rainfall data were recorded at one-minute intervals with a precision of $1 \mathrm{~mm}$, which aimed to record the heavy storm rainfall. The five-year rainfall data (one-minute interval) from 2008 to 2012 at Sites 1 and 2, and the three-year rainfall data from 2014-2017 at Sites 3-6, were obtained in order to develop the rain hyetographs, respectively.

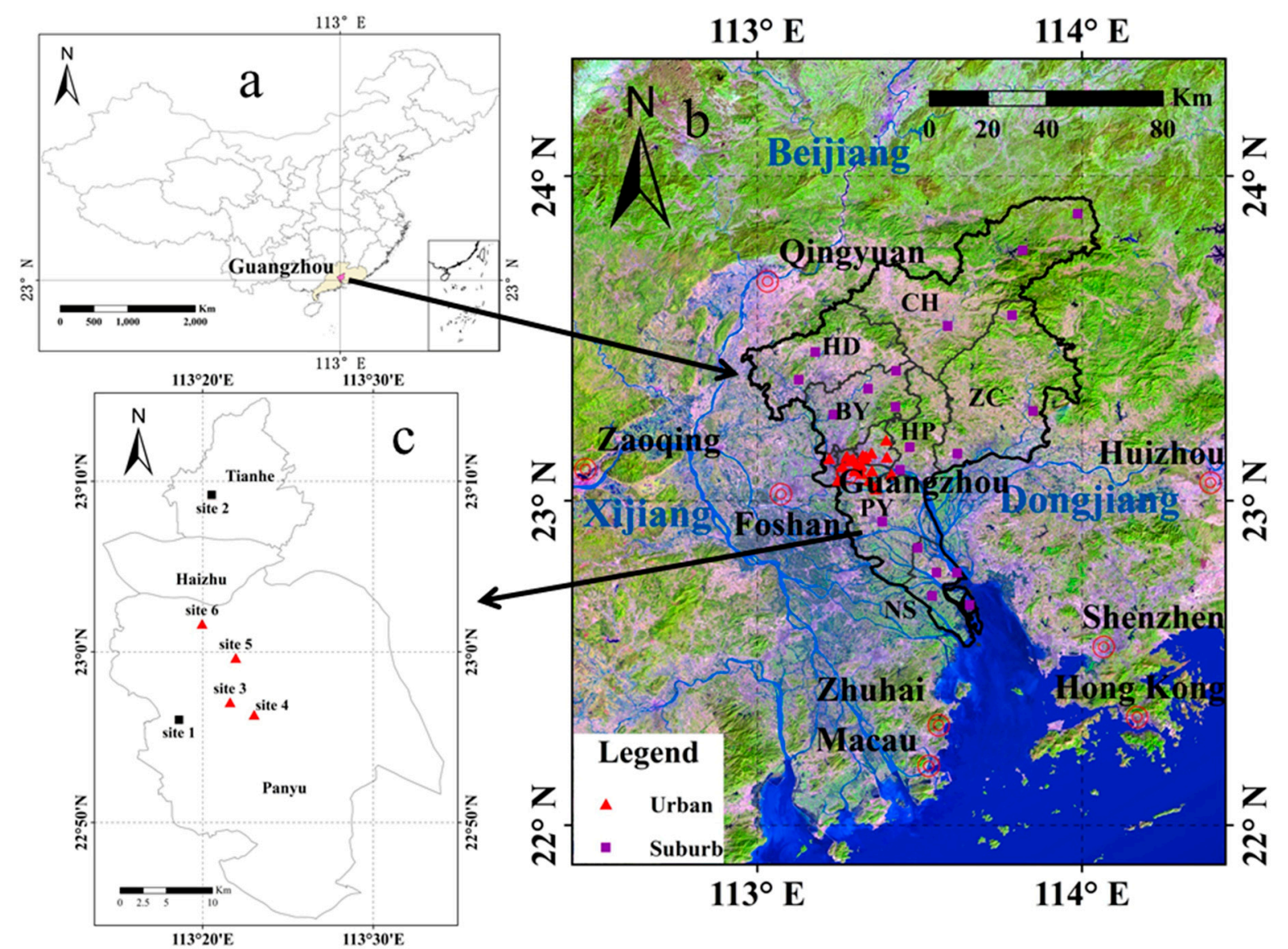

Figure 1. Meteorological sites (urban: 23 triangles; suburban: 19 squares) in the administration areas of Guangzhou (b), South China. The urban areas include the four districts of Haizhu, Liwan, Tianhe, and Yuexiu, and the suburban areas comprise the seven districts of Baiyun (BY), Huadu (HD), Conghua $(\mathrm{CH})$, Zengcheng (ZC), Huangpu (HP), Panyu (PY), and Nansha (NS). Map (c) shows the meteorological sites in the Panyu District, where Sites 3-6 are maintained by our research team, and Sites 1 and 2 are the national standard meteorological sites.

\subsection{China Hourly Merged Precipitation Analysis (CMPA)}

The China Hourly Merged Precipitation Analysis (CMPA) data merged the hourly precipitation products with $0.1^{\circ} \times 0.1^{\circ}$ spatial resolution [38] (http://cdc.nmic.cn/home.do), and are available from 2008 to present. They show a much better performance in quantifying the extreme rainfall than the other satellite and reanalysis precipitation data in China [11,38,39]. The CMPA data are used to illustrate the spatial distributions of five typical storms for the peak intensity and event total precipitation. 


\section{Methodology}

\subsection{Storm Events Classification}

This study does not analyze all of the rain events and only focuses on heavy storms, as they can produce a severe impact on meteorological factors and cause surface flooding. Storm events are identified at the individual stations based on the following criteria: (a) rain duration $>20 \mathrm{~min}$ for one-minute data or one hour for hourly data [40], (b) rain depth in a one-hour moving window $>20 \mathrm{~mm}$, and (c) storm event separation with an hourly rain depth $<1 \mathrm{~mm}$ for at least for three hours [41]. According to these criteria, there were 2611 storms at Sites 1 to 6 during 1990-2017, which were used to analyze the storm features. Among them, there were 214 storms recorded at Sites 1-2 from 2008 to 2012 and at Sites 3-6 from 2014 to 2017, using the one-minute interval. There were another 1454 storms at the 42 weather stations from July 2015 to October 2017. The 1454 storms were not physically separate storm events defined in meteorology, and occurred in Guangzhou. Some of them were actually the same storm events that occurred at the same or at a slightly later time in the metropolitan areas of Guangzhou, but were recorded at different weather stations. Those storm events at the 42 weather stations were mainly used to analyze the variations of the meteorological factors along the process of storm development and evolution.

In order to analyze the interactions between the storm (rainfall) and meteorological factors (air temperature, relative humidity, surface pressure, and wind speed), the 42 weather stations were first divided into urban and suburban groups using the K-means cluster analysis, while considering their location and neighboring land use/cover (Figure 1b). The K-means cluster algorithm set the initial center values of the meteorological variables for the two clusters of urban and suburban, and then calculated their minimum squared distance from the samples to their centers iteratively [11,42]. Finally, all of the stations were classified into the two clusters by the K-means cluster analysis using the time series of the hourly observations of the five meteorological factors for each storm event in this study. There were 23 urban stations (55\%) and 19 suburban (Figure 1b) stations. All of the heavy storm events at both the urban and suburban clusters were generally classified into five types according to the season or the locations of the subtropical high, which determines the vapor source and forming mechanisms of heavy storms $[9,10]$. They are (a) warm-front storms (occurred in January), (b) cold-front storms (April to mid-May), (c) monsoon storms (late May to June), (d) convective storms (July to September), and (e) typhoon storms (July to September). The typhoon storms were precisely identified.

The cold-front storms, monsoon storms, and convective storms were further divided into three groups by occurrence time (i.e., 8:00-12:00, 13:00-18:00, and 19:00-0:00-7:00), so as to assess the impact of the heavy storms on the meteorological factors during the storm process in different periods/solar radiation, and thus could better analyze their interaction with storms. Warm-front and typhoon storms had a limited storm count and did not have such an analysis carried out.

\subsection{Anomaly Curves}

After the storm events were classified, anomaly curves $36 \mathrm{~h}$ prior to and post the storm peak hour were generated so as to analyze the impact on and the interaction of the storms with meteorological factors. The reference values are the diurnal mean of each factor during two weeks centered on the storm time, excluding their values during the 72-h period affected by the storm. The anomalies are the residuals between the actual meteorological factors' value and their reference value during the $72 \mathrm{~h}$ centered at the storm peak intensity hour.

\subsection{Rain Hyetograph}

The rain hyetographs in this study are derived by the Improved Huff curve model reported by Pan et al. [5]. The Huff curve is a dimensionless hyetograph initially developed by Huff for characterizing rainfall temporal distributions in an area, and has been widely applied to describe the hyetograph and to predict the runoff in a catchment [43-46]. In traditional analysis, the storm 
events are first classified into four quartiles according to their normalized time of peak rain intensity. Next, a quartile curve is developed at a certain provability, normally varying from $10 \%$ to $90 \%$, by a $10 \%$ increment. Then, a series of Huff curves are developed at different probabilities within each quartile [46]. The $50 \%$ probability (median) curve is the most representative in each quartile.

The improved Huff curve method does not separate storms into the four quartiles as usual, but divides each storm into the rising and falling limbs, according to the occurrence time of the peak rain intensity [5]. Then, the dimensionless hyetographs are developed by the Huff curve method based on the normalized rain intensity and the time in the rising and falling limbs separately. Finally, both of the hyetographs are combined to form an Improved Huff curve. The Improved Huff curves in this study were developed at the probability of $50 \%$ in both the rising and falling limbs, based on the one-minute rainfall data of Sites 1-6 from 2008 to 2017.

\subsection{Precipitation Extremes and Temperature Scaling}

The approach of Clausius-Clapeyron (CC) scaling is applied in order to assess the impact of air temperature on precipitation extremes in the subtropical Guangzhou, based on all of the available hourly precipitation and temperature data [12]. Only the hourly precipitation data are analyzed. The daily mean air temperature is computed from the hourly temperature data during the 24-h period prior to the storm, as well as the natural daily mean temperature. The precipitation data were stratified based on the 24-h and daily mean air temperature in bins of $2{ }^{\circ} \mathrm{C}$ widths, within which the precipitation extremes were computed from the 75th, 90th, 99th, and 99.9th percentiles. Only the 75th and 99th percentiles have been presented for graph clarity $[47,48]$.

\section{Results and Discussions}

\subsection{Characteristics of Meteorological Factors}

The administration area of Guangzhou is located in the upper Pearl River Delta (PRD), facing the low-lying delta plain in West and South China Sea in the southeast, and surrounded by hills in the North and East (Figures 1b and 2a). At the 42 weather stations from July 2015 to October 2017, the main wind direction during the storm duration was from the south $(42 \%)$ and east $(28 \%)$, followed by the west $(19 \%)$ and a few $(11 \%)$ from the north. The suburban districts of Baiyun, Huangpu, Zengcheng, and Conghua had much larger precipitation than the downtown area of Guangzhou (Figure 2b). Meanwhile, attention must be paid to the big orange area, which has less precipitation as a result of the statistical artifacts caused by lack of weather stations in the hills, and thus its actual annual precipitation could be larger. In the downtown areas of Guangzhou with more weather stations, the urban stations showed distinct patterns of meteorological factors from the suburban stations, that is, less precipitation (Figure 2b), higher air temperature (Figure 2c), lower relative humidity (Figure 2d), lower surface pressure (Figure 2e), and smaller wind speed (Figure 2f) at the urban stations compared with the suburban stations. Considering the short duration of the records, they were just the typical mean states for this area. The precipitation extremes were also found to be positively associated with the urban extent in the Pearl River Delta [39]. 

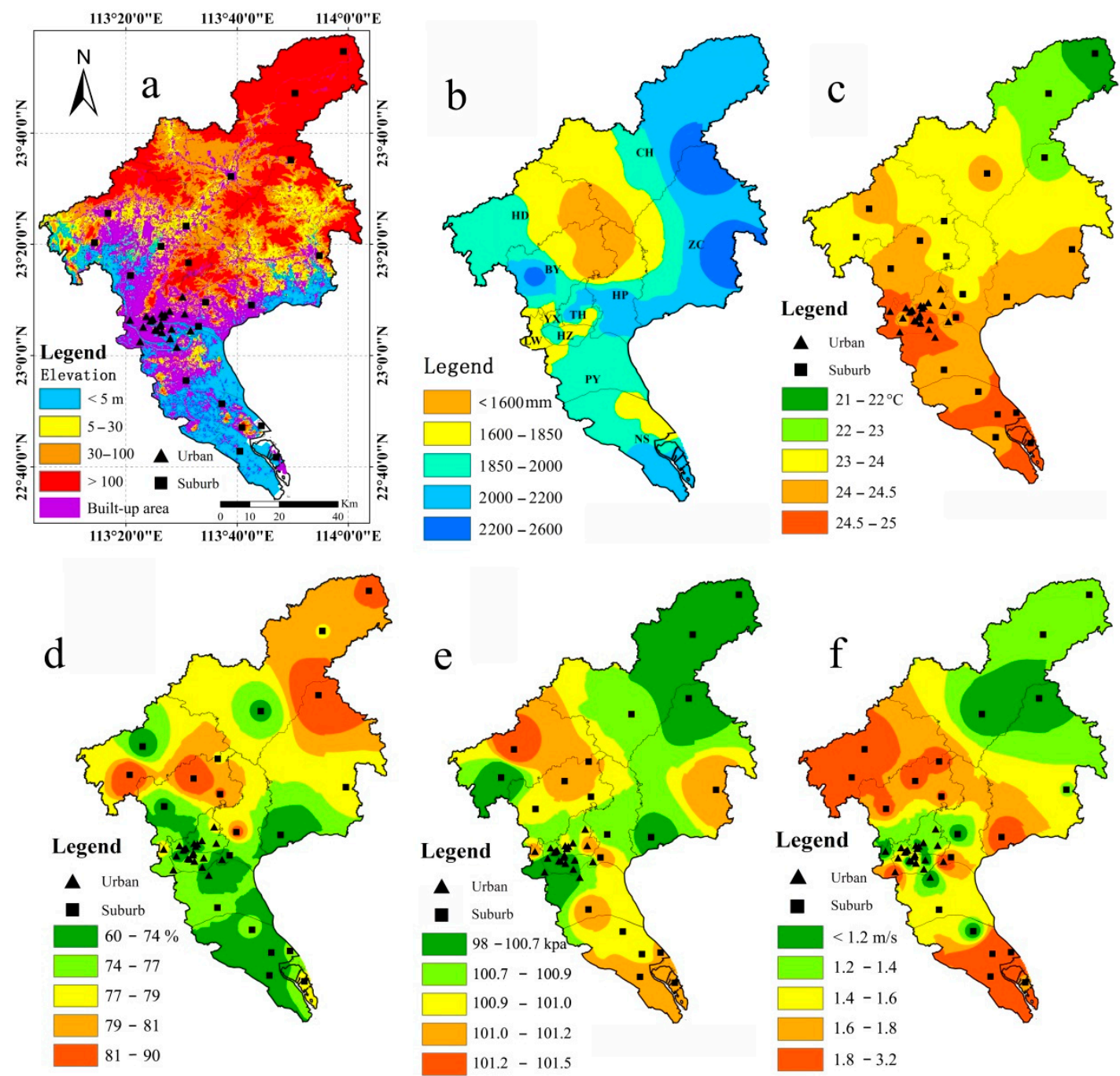

Figure 2. The elevation and built-up areas of Guangzhou and the locations of the meteorological sites (a), annual total rainfall (b), annual mean air temperature (c), relative humidity (d), air pressure (e), and wind speed (f) for two complete years from July 2015 to June 2017.

Besides the annual scale, meteorological factors also demonstrated different patterns for urban and suburban stations at the seasonal and diurnal scales (Figure 3). The urban stations had less rainfall in the first rainy season, from April to June, than the suburban stations, while they had larger rainfalls in the second rainy season of July, September, and October (Figure 3a). At the diurnal cycle, all of the stations showed two peaks of storm events in the morning and afternoon. The urban stations had a shorter duration in the morning peak and a longer duration in the afternoon peak than the suburban stations (Figure 3b). The surface air temperature and pressure showed an inverse temporal pattern at the seasonal scale (Figure $3 c, g$ ), while the temperature and relative humidity had an inverse temporal pattern at the diurnal scale (Figure 3d,f). The air pressure also showed a semidiurnal pattern (Figure 3h). Similar to the annual scale, the urban stations generally had a higher temperature, lower humidity and pressure, and much smaller wind speed than the suburban stations (Figure 3). 

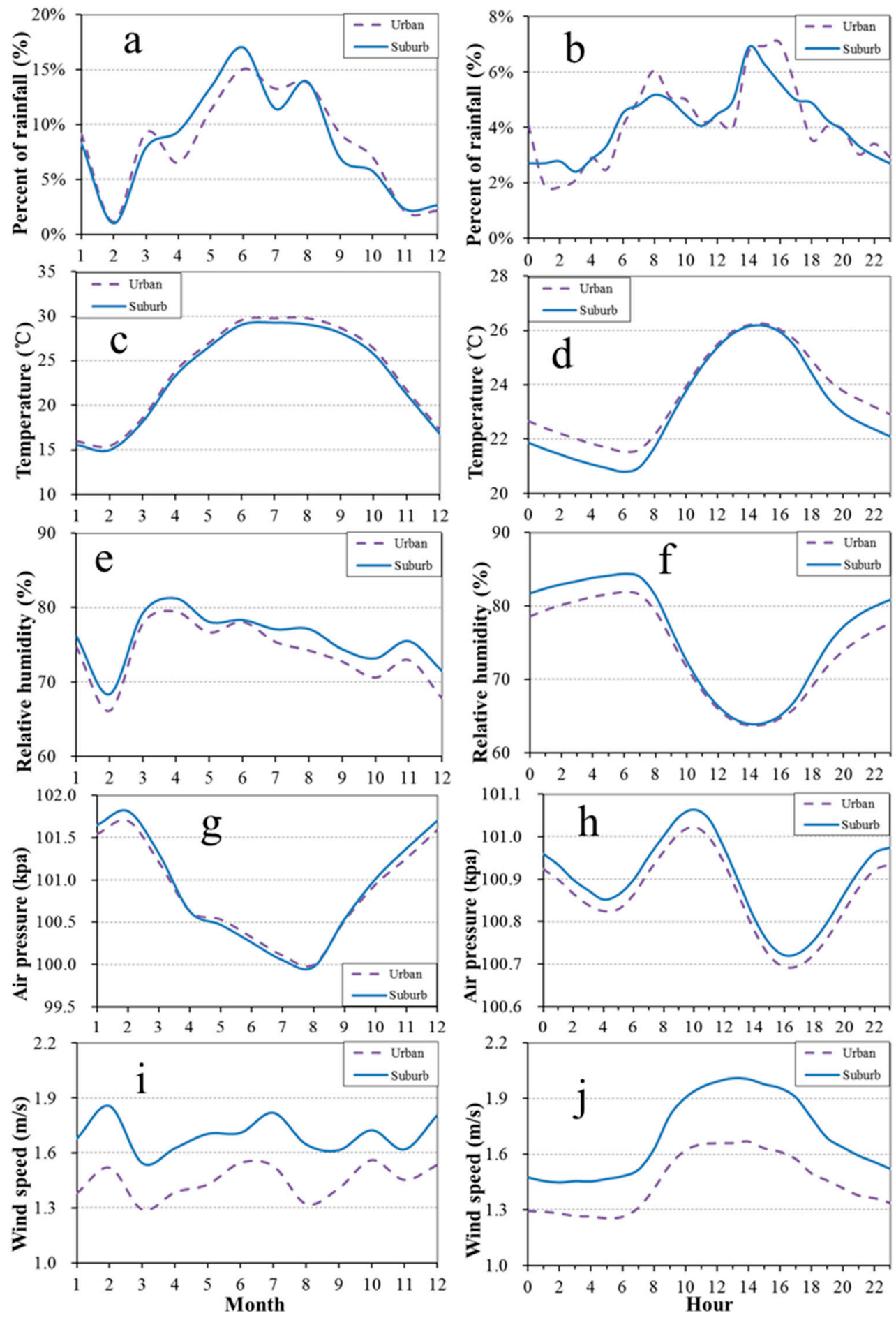

Figure 3. The seasonal (monthly) and diurnal (hourly) distributions of $(\mathbf{a}, \mathbf{b})$ rainfall, $(\mathbf{c}, \mathbf{d})$ surface temperature, $(\mathbf{e}, \mathbf{f})$ relative humidity, $(\mathbf{g}, \mathbf{h})$ air pressure, and $(\mathbf{i}, \mathbf{j})$ wind speed at the urban and suburban sites in Guangzhou from July 2015 to October 2017.

\subsection{Characteristics of Storms}

The storm features displayed little differences between the urban and suburban stations at an event scale, with a similar storm duration, event total, and intensity (Table 1). Half of the storms had an event duration of less than three hours, nearly a quarter of them were three to five hours, and over another quarter were longer than five hours, based on all of the hourly storm rainfall data from 1990 to 2017 (Table 1). 
Table 1. Statistics of storm events at Sites 1-6 for the hourly rainfall data from 1990 to 2017.

\begin{tabular}{|c|c|c|c|c|c|c|c|c|}
\hline \multirow{2}{*}{ Stations } & \multirow{2}{*}{$\begin{array}{l}\text { Storm } \\
\text { Count }\end{array}$} & \multicolumn{4}{|c|}{ Duration (h) } & \multirow{2}{*}{$\begin{array}{l}\text { Mean (h) } \\
\text { Duration }\end{array}$} & \multirow{2}{*}{$\begin{array}{l}\text { Mean }(\mathrm{mm}) \\
\text { Event Total }\end{array}$} & \multirow{2}{*}{$\begin{array}{l}\text { Mean }(\mathrm{mm} / \mathrm{h}) \\
\text { Rain Intensity }\end{array}$} \\
\hline & & $\leq 1$ & $1-3$ & $3-5$ & $>5$ & & & \\
\hline \multirow{2}{*}{ Urban } & \multirow{2}{*}{1327} & 165 & 505 & 297 & 360 & \multirow{2}{*}{4.4} & \multirow{2}{*}{46} & \multirow{2}{*}{10.5} \\
\hline & & $12 \%$ & $38 \%$ & $23 \%$ & $27 \%$ & & & \\
\hline \multirow{2}{*}{ Suburb } & \multirow{2}{*}{1284} & 144 & 493 & 292 & 355 & \multirow{2}{*}{4.6} & \multirow{2}{*}{47} & \multirow{2}{*}{10.3} \\
\hline & & $11 \%$ & $38 \%$ & $23 \%$ & $28 \%$ & & & \\
\hline
\end{tabular}

The occurrence time of the peak rainfall plays a crucial role in determining the temporal distribution of the storm rainfall, that is, the rain hyetograph, which further impacts on the design storm, local drainage planning/design, and flooding risk. Figure 4 illustrates the rain hyetographs for the four types of summer storms at urban and suburban stations using the improved Huff curve established by Pan et al. [5]. Table 2 summarizes the statistics of these storms used in Figure 4. The urban stations had similar hyetographs, for example, having a similar peak rainfall occurrence time ( $29 \%-32 \%$ of event duration) and peak rainfall percentage ( $52 \%-57 \%$ of total rainfall) during a 0.5-h peak rainfall time. In contrast, the suburban stations had a wider range and later peak rainfall occurrence time $(30 \%-41 \%)$ and a larger range $(45 \%-61 \%)$ of peak rainfall percentage. The difference in the storm hyetograph will generate a different peak runoff, requiring a different drainage capability even for a same scale storm event. This indicates that different rain hyetographs are required in the storms for the design of drainage planning and flooding infrastructure in urban and suburban areas, even in the same administration area of Guangzhou [5].
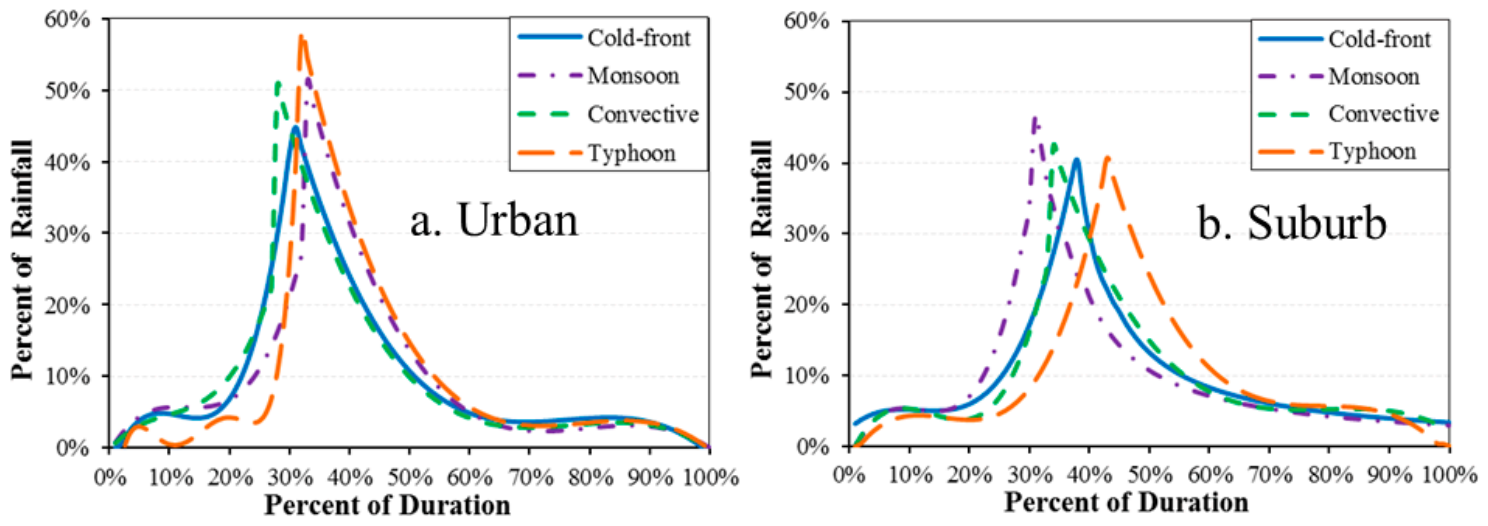

Figure 4. Storm hyetographs derived from the Improved Huff curve model at a probability of 50\% from the one minute-interval rainfall data at Sites 1-2 during 2008-2012, and Sites 3-6 from 2014-2017 for the cold-front storms, monsoon storms, convective storms, and typhoon storms in (a) urban and (b) suburban areas. 
Table 2. Statistics of storm events for the one minute-interval data during 2008-2012 (Sites 1-2) and 2014-2017 (Sites 3-6). The peak rainfall time is determined using the maximum five-minute rainfall accumulation. The rainfall time is normalized using the total rainfall duration.

\begin{tabular}{|c|c|c|c|c|c|c|c|c|}
\hline \multirow{2}{*}{ Stations } & \multirow{2}{*}{$\begin{array}{l}\text { Storm } \\
\text { Types }\end{array}$} & \multirow{2}{*}{$\begin{array}{l}\text { Event Mean } \\
\text { Rainfall (mm) }\end{array}$} & \multirow{2}{*}{$\begin{array}{c}\text { Percent of Max } \\
\text { 0.5h Rainfall }\end{array}$} & \multirow{2}{*}{$\begin{array}{l}\text { Peak Rainfall } \\
\text { Time }\end{array}$} & \multicolumn{2}{|c|}{ Rainfall Depth } & \multicolumn{2}{|c|}{ Intensity $(\mathrm{mm} / \mathrm{min})$} \\
\hline & & & & & Rising & Falling & Rising & Falling \\
\hline \multirow{4}{*}{ Urban } & Cold-front & 45 & $52 \%$ & $29 \%$ & $40 \%$ & $60 \%$ & 0.64 & 0.31 \\
\hline & Convective & 41 & $57 \%$ & $28 \%$ & $41 \%$ & $59 \%$ & 0.77 & 0.39 \\
\hline & Typhoon & 29 & $57 \%$ & $32 \%$ & $31 \%$ & $69 \%$ & 0.17 & 0.20 \\
\hline & Mean & 41 & $55 \%$ & $29 \%$ & $42 \%$ & $58 \%$ & 0.68 & 0.33 \\
\hline \multirow{4}{*}{ Suburban } & Monsoon & 52 & $49 \%$ & $30 \%$ & $37 \%$ & $63 \%$ & 0.64 & 0.40 \\
\hline & Convective & 36 & $61 \%$ & $33 \%$ & $42 \%$ & $58 \%$ & 0.67 & 0.44 \\
\hline & Typhoon & 34 & $45 \%$ & $41 \%$ & $50 \%$ & $50 \%$ & 0.32 & 0.21 \\
\hline & Mean & 46 & $54 \%$ & $32 \%$ & $40 \%$ & $60 \%$ & 0.69 & 0.45 \\
\hline
\end{tabular}

Table 3 summarizes the storm information recorded at the 42 weather stations from July 2015 to October 2017. The coastal zone had more rainfall than the inner land for the warm-front events (Figure 5b). There were only two actual warm-front events that occurred during 27-29 January 2016. For example, one, which occurred on 28 January 2016, was a wide spread and long-duration storm (Figure 5a,b), and most of the stations reported this storm. Another storm on 27 January 2016 had a smaller intensity, and only a few stations reported it as a storm event. This explained why there were 50 storm events at the 42 weather stations for the actual two events.

Table 3. Statistics of the storms at the 42 weather stations from July 2015 to October 2017.

\begin{tabular}{cccccccc}
\hline \multirow{2}{*}{ Items } & Stations & All & $\begin{array}{c}\text { Warm-Front } \\
\text { Storm }\end{array}$ & $\begin{array}{c}\text { Cold-Front } \\
\text { Storm }\end{array}$ & $\begin{array}{c}\text { Monsoon } \\
\text { Storm }\end{array}$ & $\begin{array}{c}\text { Convective } \\
\text { Storm }\end{array}$ & $\begin{array}{c}\text { Typhoon } \\
\text { Storm }\end{array}$ \\
\hline \multirow{2}{*}{ Storm Count } & Urban (23) & 752 & $* 3 \%$ & $13 \%$ & $26 \%$ & $50 \%$ & $8 \%$ \\
\cline { 2 - 8 } & Suburb (19) & 702 & $* 4 \%$ & $23 \%$ & $29 \%$ & $39 \%$ & $7 \%$ \\
\hline Storm & Urban & 3.2 & 7.8 & 3.3 & 3 & 2.6 & 5.9 \\
duration (h) & Suburb & 3.6 & 11.9 & 3.2 & 3.3 & 2.9 & 6 \\
\hline Mean rainfall & Urban & 41.3 & 82.1 & 37.9 & 37.4 & 41 & 43.8 \\
(mm/event) & Suburb & 44.0 & 83.1 & 37.2 & 37.9 & 43.3 & 76.7 \\
\hline Mean rain rate & Urban & 12.8 & 10.5 & 11.5 & 12.5 & 15.8 & 7.4 \\
(mm/h) & Suburb & 12.2 & 7.0 & 11.6 & 11.5 & 14.9 & 12.8 \\
\hline Storm count & Urban & $\# 25 \%$ & $52 \%$ & $19 \%$ & $26 \%$ & $24 \%$ & $19 \%$ \\
$8: 00-12: 00$ & Suburb & $\# 19 \%$ & $40 \%$ & $16 \%$ & $17 \%$ & $20 \%$ & $15 \%$ \\
\hline Storm count & Urban & $\# 40 \%$ & $0 \%$ & $38 \%$ & $30 \%$ & $51 \%$ & $28 \%$ \\
13:00-18:00 & Suburb & ${ }^{\#} 41 \%$ & $12 \%$ & $42 \%$ & $43 \%$ & $42 \%$ & $34 \%$ \\
\hline Storm count & Urban & $\# 35 \%$ & $48 \%$ & $43 \%$ & $44 \%$ & $25 \%$ & $52 \%$ \\
19:00-7:00 & Suburb & ${ }^{\#} 40 \%$ & $48 \%$ & $41 \%$ & $40 \%$ & $37 \%$ & $51 \%$ \\
\hline$*$ Mean storm & Urban & 926 & 88 & 235 & 161 & 414 & 28 \\
rainfall (mm) & Suburb & 1056 & 117 & 374 & 217 & 312 & 36 \\
\hline \#\# Mean total & Urban & 2708 & 296 & 530 & 734 & 1095 & 53 \\
rainfall (mm) & Suburb & 2822 & 289 & 609 & 860 & 1014 & 50 \\
\hline
\end{tabular}

Note: ${ }^{*}=$ count percentage of each storm type against all of the storm events. \# = count percentage of the morning, afternoon, and night for each storm type, against those that occurred all day. ${ }^{* *}=$ mean storm rainfall at each site. \#\# = mean total rainfall, including storms and no storm, at each site.

The cold-front storms were fast moving and wide spreading (Figure $5 c, d$ ). The suburban stations (158) had more storms than the urban stations (94) (Table 3). The afternoon had more storms than the morning and night on average, for example, a quarter of a day $(6 \mathrm{~h})$ in the afternoon had $38 \%$ and $42 \%$ of all of the storms in the urban and suburban stations, respectively. 

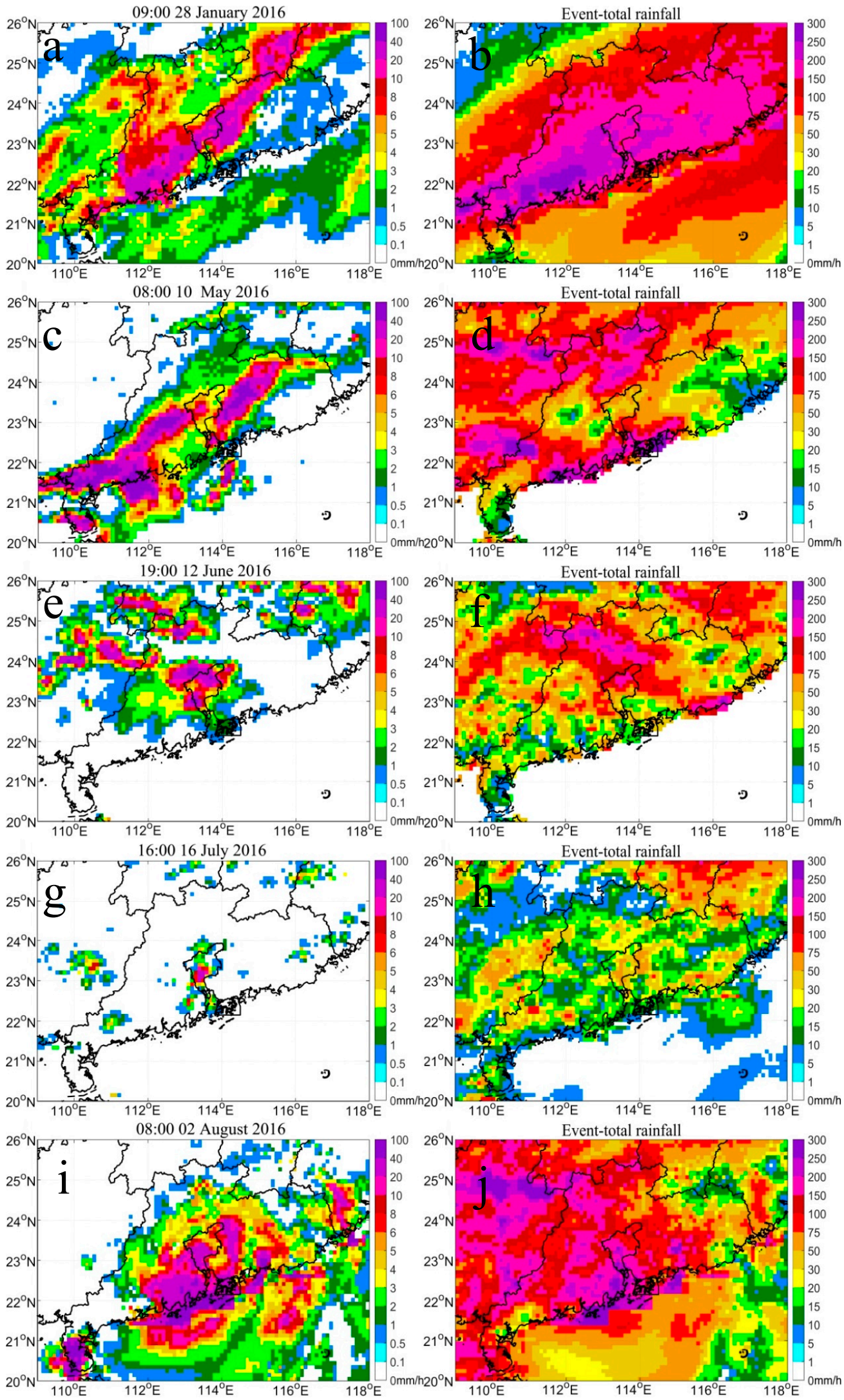

Figure 5. The spatial distribution of the peak rainfall and event-total rainfall plotted from the China Hourly Merged Precipitation Analysis (CMPA) product for five typical storm events (types) that occurred in the metropolitan areas of Guangzhou, China, that is, a warm-front storm (a,b), a cold-front storm $(\mathbf{c}, \mathbf{d})$, a monsoon storm $(\mathbf{e}, \mathbf{f})$, a convective storm $(\mathbf{g}, \mathbf{h})$, and the typhoon Nida storm $(\mathbf{i}, \mathbf{j})$. 
Monsoon storms were the second most recorded storms next to convective storms, $26 \%$ in urban and $29 \%$ in suburban (Table 3). They had a similar rain duration and rain depth, but a smaller rainfall range than the cold-front storms (Figure 5e,f). The urban stations had more storms in the morning and less storms in the afternoon than the suburban stations, plus an overall shorter duration.

Most of the convective storms were localized and small-range events (Figure 5g,h), while they had the shortest duration and the largest mean intensity, resulting in most of the urban waterlogging incidents (Table 3). They were dominant in both the urban (50\%) and suburban (39\%) stations. The afternoon had the most events, especially in the urban areas (51\%), due to strong solar radiation and the urban heat island effect.

The typhoon-brought storms were the most-wide spreading (Figure $5 \mathrm{i}, \mathrm{j}$ ), and had the second longest rain duration following the warm-front storms (Table 3). They were near evenly distributed through the day. The suburban stations had much more rainfall and a stronger rain rate than the urban stations.

\subsection{Variations of Meteorological Factors with Storms}

The interactions between the storm and meteorological factors were investigated from two aspects. Firstly, five storm events that occurred at a typical station were used to illustrate their specific interactions (Figure 6). Then, the mean conditions of all events were divided into three storm occurrence periods of morning, afternoon, and night time, so as to show the impact of solar radiation on their interactions with cold-front storms, monsoon storms, and convective storms (Figures 7-9). Warm-front and typhoon storms were not separated into these three periods because of their limited storm count.

\subsubsection{Warm-Front Storms (in January)}

The development of warm-front storms was mainly caused by the El Nino effect, a special case in Guangzhou and Southern China in January 2016. They were controlled by the cold air in the winter time, and then encountered the warm moist air that moved up from the Bengal Bay and the South China Sea. During the two weeks centered on 27-29 January 2016, the mean diurnal air temperature varied between $10{ }^{\circ} \mathrm{C}$ and $13^{\circ} \mathrm{C}$ one week prior to and post storm, while it decreased to $5{ }^{\circ} \mathrm{C}$ prior to the storm and increased to $18^{\circ} \mathrm{C}$ after the storm, resulting in a mean storm total of $90 \mathrm{~mm}$ (Figure 6a). The warming effect lasted over three days after the storm. As the warm and moist air moved up and the temperature increased, the relative humidity dramatically increased from $25 \%$ to above $80 \%$ (Figure 6b), the surface pressure was lower than the normal mean prior to and during the storm, and was higher than the normal after the storm (Figure $6 \mathrm{c}$ ). The wind speed had a much larger variation than the normal mean (Figure $6 \mathrm{~d}$ ).

\subsubsection{Cold-Front Storms (April to Mid-May)}

The cold-front storms are controlled by the southwesterly wind (northeasterly) in South China, before the South China Sea summer monsoon is formed $[9,10]$. It generates a heavy storm center in Qingyuan and Shaoguan, the northern Guangzhou, mainly because of the uplifting effect of the topography (Figures $1 \mathrm{~b}$ and $5 \mathrm{~d}$ ). The suburban stations (158 events) in Northern Guangzhou had much more cold-front storms than the urban stations (94 events) (Table 3).

Taking the storm on 9-11 May 2016 as an example, the air temperature rose by $2{ }^{\circ} \mathrm{C}$ above the two-week diurnal mean before the cold front arrived, and it dramatically decreased from $32{ }^{\circ} \mathrm{C}$ to $23^{\circ} \mathrm{C}$ within $20 \mathrm{~h}$ as the cold front was approaching and the storm was formed (Figure 6e). It returned to the normal diurnal variations about $24 \mathrm{~h}$ after the storm ended. Relative humidity always accompanied the air temperature changes in an inverse pattern, that is, a lower and higher relative humidity than the diurnal mean immediately before and after the storm (Figure $6 \mathrm{f}$ ). The surface pressure was lower than the diurnal mean $24 \mathrm{~h}$ before the storm, and the difference was reduced after the storm. It returned to 
the normal variation $12 \mathrm{~h}$ after the storm (Figure $6 \mathrm{~g}$ ). There was a larger wind speed about $20 \mathrm{~h}$ prior to the storm, and it fell back to the normal variations during and after the storm (Figure 6h).
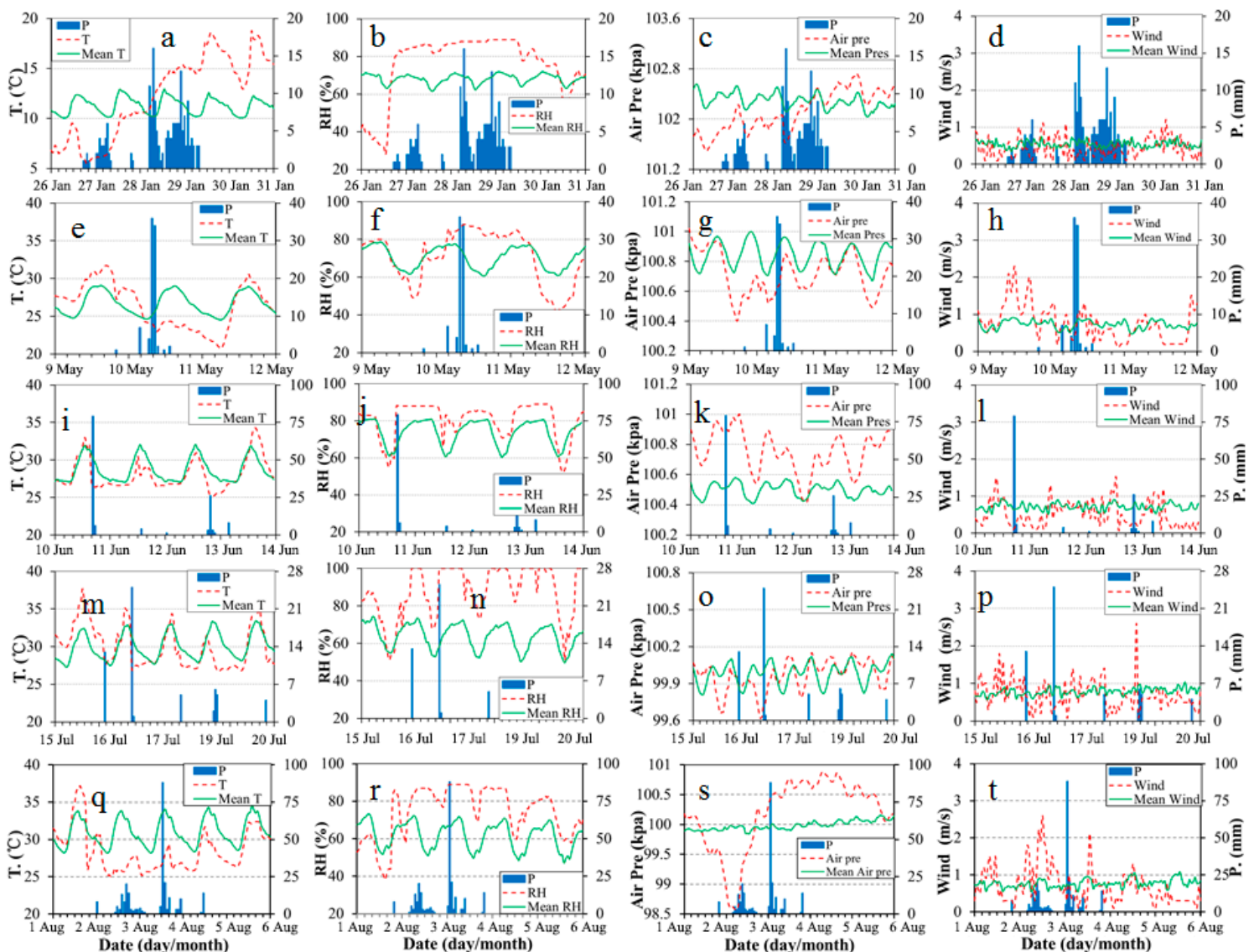

Figure 6. The fluctuations of air temperature, relative humidity, surface pressure, and wind speed at an urban station for a warm-front storm on 27-29 January 2016 (a-d), a cold-front storm on 9-11 May 2016 (e-h), a monsoon storm on 9-15 June 2016 (i-1), a convective storm on 14-20 July 2016 (m-p), and the typhoon Nida storm on 1-4 August $2016(\mathbf{q}-\mathbf{t})$. The green lines are the diurnal average during a two-week period centered at but excluded from the storm-affecting duration. This urban station (G3221) is located in the Tianhe District downtown of Guangzhou.

The impact of the storms on the meteorological factors were investigated by dividing the occurrence time into morning 8:00-12:00 (Figure 7a-d), afternoon 13:00-18:00 (Figure 7e-h), and night time 19:00-7:00 (Figure 7i-1). Prior to and after the storm, there were overcast clouds, which blocked the shortwave solar radiation and retained the Earth's surface long wave radiation. The storms disturbed the normal diurnal variation of the meteorological factors, among which the air temperature was most impacted. When the storm occurred in the morning, the air temperature was $+6^{\circ} \mathrm{C}$ higher than the diurnal mean about $24 \mathrm{~h}$ prior to the storm, lasted about $8 \mathrm{~h}$ at that anomaly high status, and then dramatically decreased to $-4{ }^{\circ} \mathrm{C}$ after the storm (Figure 7a). It decreased at a larger magnitude and longer duration at the urban stations than at the suburban stations.

When the storm occurred in the afternoon, the air temperature was $+2{ }^{\circ} \mathrm{C}$ higher than the diurnal mean about $18 \mathrm{~h}$ prior to the storm, lasted about $6 \mathrm{~h}$ at that positive status, and then dramatically decreased to $-4{ }^{\circ} \mathrm{C}$ immediately before the storm (Figure 7e). The cooling effect was reduced quickly after the storm, and the urban stations had a much larger cooling magnitude than the suburban stations.

When the storm occurred in night, the air temperature was $+2{ }^{\circ} \mathrm{C}$ higher than the diurnal mean about $12 \mathrm{~h}$ prior to the storm, lasted about $12 \mathrm{~h}$ at that positive status and then immediately decreased to $-2{ }^{\circ} \mathrm{C}$ during the storm (Figure 7i). The cooling impact lasted $12 \mathrm{~h}$ after the storm. The mean 
wind speed was higher than the diurnal mean $12 \mathrm{~h}$ prior to, and after the storm at the urban stations (Figure 71).
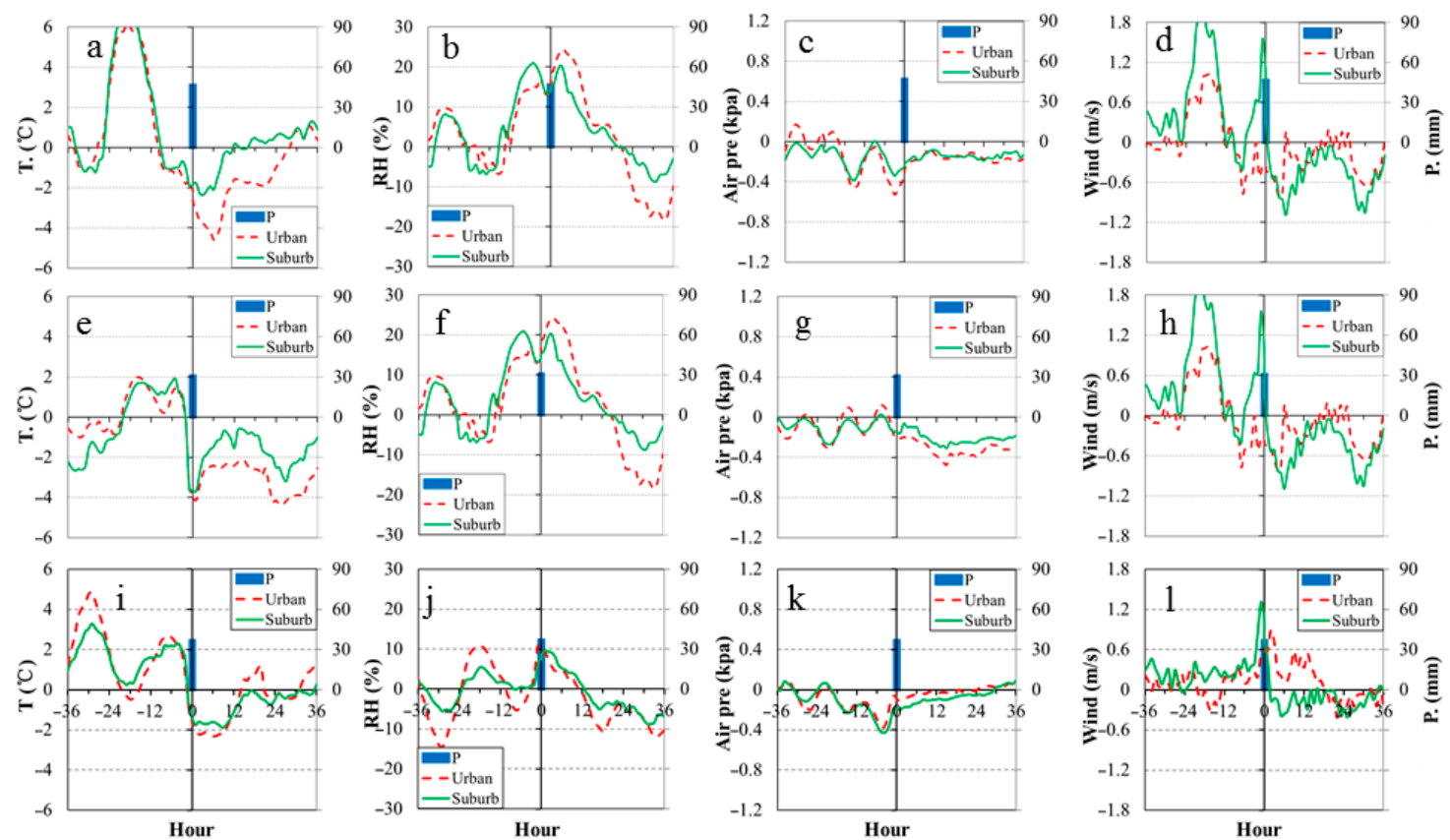

Figure 7. Anomalies of air temperature, relative humidity, surface pressure, and wind speed $36 \mathrm{~h}$ prior to, and after the cold-front storms that occurred in the morning (8:00-12:00; a-d), afternoon (13:00-18:00; e-h), and night (19:00-7:00; i-1). The references are the diurnal mean during a two-week period centered at but excluded from the $72 \mathrm{~h}$ of storm period from July 2015 to October 2017. The precipitation in the right-hand axis is the mean event-total rainfall.

\subsubsection{Monsoon Storms (Late May to June)}

When the southwesterly (northeasterly) wind weakened in the mid-May, the southeasterly strengthened and then dominated the monsoon rains in late May and June in South China [9]. One important feature of the South China Sea summer monsoon onset is that the upper tropospheric $(100 \mathrm{hPa})$ zonal wind shifts from westerly to easterly, corresponding to the northward move of the South Asia High [10]. Thus, the storms occurring in late May and June are caused mainly by the warm and moist South China Sea summer monsoon. Both the cold frontal and monsoonal rain are the dominant rain sources in the first rainy season, from April to June. They normally form a storm center in the southeast coast during the monsoon rain period (Figure 5f). The monsoon rain decreased from the southeastern coast to the northwestern inland [9]. The monsoon storms had similar storm durations, event total rainfall, and mean rain rates to the cold-front storms (Table 3). There were more monsoon storms that occurred in the afternoon, especially at the suburban stations.

The monsoon storms did not form an evident front, such as the storm event that occurred on 12 June 2016 (Figure 5e,f). The air temperature did not show obviously changes before the storm, but immediately decreased during the storm (Figure 6i). Both the relative humidity and surface pressure were higher than the two-week diurnal mean for a few days after the storm (Figure 6j,k). The wind speed was larger and smaller than the diurnal mean several hours prior to and after the storm, respectively (Figure 61).

When storms occurred in the morning, the air temperature was $+3{ }^{\circ} \mathrm{C}$ higher than the diurnal mean about $20 \mathrm{~h}$ prior to the storm, lasted about $6 \mathrm{~h}$ at that positive status, and then decreased to $-3^{\circ} \mathrm{C}$ two hours prior to the storm. This negative value reduced slowly, and it returned to the normal variations $10 \mathrm{~h}$ after the storm at the urban stations (Figure 8a). The cooling impact lasted about eight hours longer at the suburban stations than at the urban stations. 
When the storm occurred in the afternoon, the air temperature was $+2{ }^{\circ} \mathrm{C}$ higher than the diurnal mean, about six hours prior to the storm, lasted about three hours at that positive status, and then dramatically decreased to $-4{ }^{\circ} \mathrm{C}$ (anomaly) during the storm (Figure 8e). The cooling impact quickly reduced after the storm and lasted about $10 \mathrm{~h}$.

When the storms occurred at night, the impact of the storms on the air temperature and other meteorological factors were reduced compared with the morning and afternoon storms (Figure 8i-1). The air temperature was $+2{ }^{\circ} \mathrm{C}$ higher than the diurnal mean about $12 \mathrm{~h}$ prior to the storm, lasted about three hours at that positive status and then decreased to $-2{ }^{\circ} \mathrm{C}$ (anomaly) during the storm (Figure 8i). The cooling impact lasted $10 \mathrm{~h}$ after the storm. The mean wind speed was higher than the diurnal mean after the storm at the urban stations, while it was lower than the diurnal mean at the suburban stations (Figure 81).
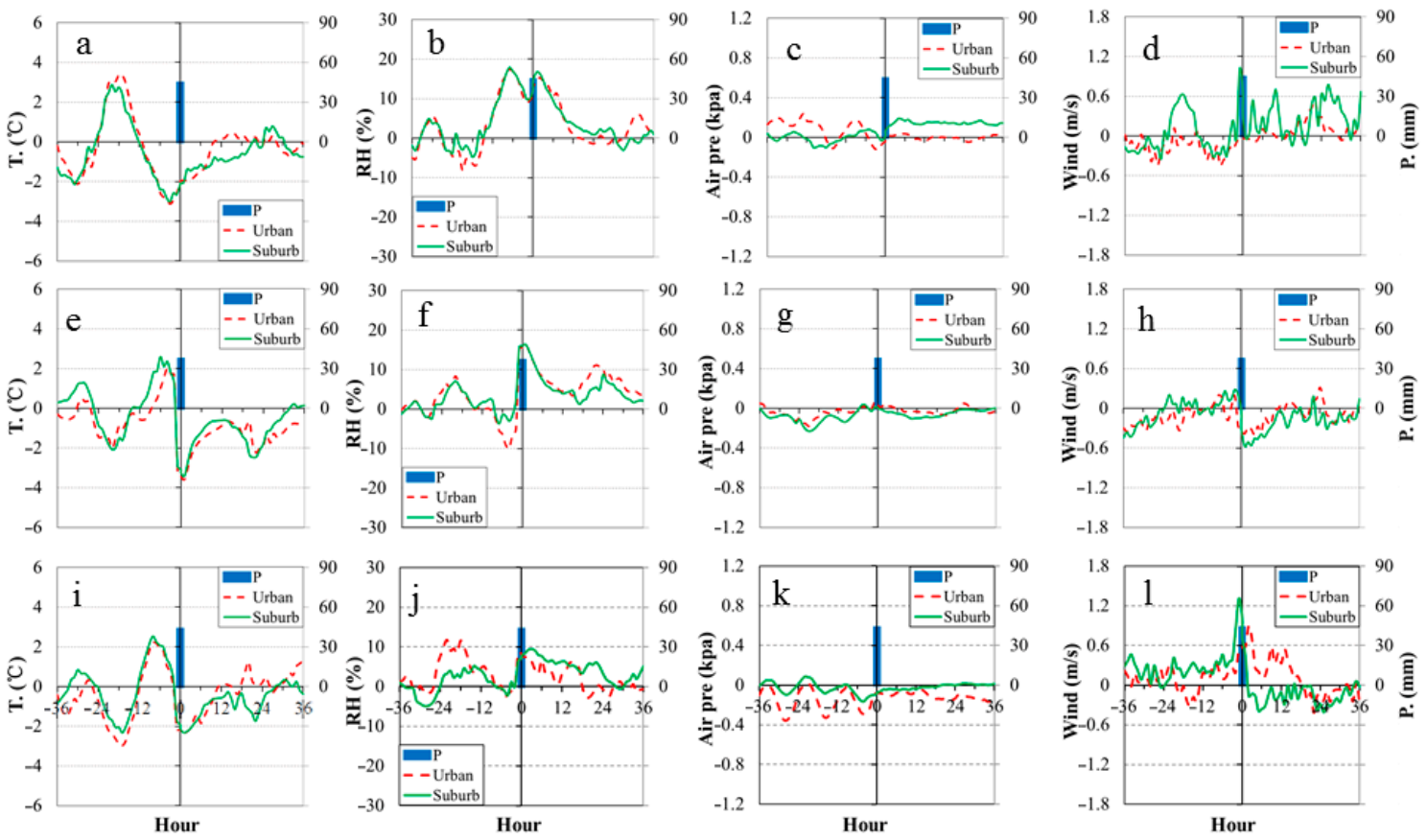

Figure 8. Anomalies of air temperature, relative humidity, surface pressure, and wind speed during $36 \mathrm{~h}$ prior to and post the monsoon storms that occurred in the morning (8:00-12:00; a-d), afternoon (13:00-18:00; $\mathbf{e - h})$, and night (19:00-7:00; $\mathbf{i}-\mathbf{1})$. The references are the diurnal mean during a two-week period centered at but excluding the $72 \mathrm{~h}$ of storm period from July 2015 to October 2017. The precipitation in the right-hand axis is the mean event-total rainfall.

\subsubsection{Convective Storms (July to September)}

There is strong solar radiation and intense surface heating in Guangzhou $\left(\sim \mathrm{N} 23^{\circ}\right)$ from 22 June to 23 September each year, when the sun can vertically shed light on the Tropic of Cancer, and then moves southward back to the equator. Such a surface heating causes intense convection, resulting in localized convective storms or thunderstorms at local (micro) scales, especially in urban areas. These storms have unique dynamical structures largely controlled by the three-dimensional air temperature, humidity, pressure, and wind in the environment of the convection developing. One example was the convective thunderstorm that occurred in Guangzhou on the morning of 16 July 2016 (Figure 5g,h). The air temperature was $+3{ }^{\circ} \mathrm{C}$ above the diurnal mean $18 \mathrm{~h}$ prior to the storm, and then decreased to $-3{ }^{\circ} \mathrm{C}$ below the mean during the storm (Figure $6 \mathrm{~m}$ ). The relative humidity was much higher than the diurnal mean prior to and after the storms (Figure $6 \mathrm{n}$ ).

The convective storms had a dominant occurrence frequency in all of the storm types at both the urban (50\%) and suburban (39\%) stations (Table 3). The afternoon had the largest share on average, while night had the least possibility, especially at the urban stations, with $51 \%$ count in the afternoon 
(13:00-18:00) and only $25 \%$ in the night. When storms occurred in the morning, the air temperature was $+5{ }^{\circ} \mathrm{C}$ higher than the diurnal mean about $20 \mathrm{~h}$ prior to the storm, lasted about four hours at that anomaly high status, and then dramatically decreased to $-4{ }^{\circ} \mathrm{C}$ (anomaly) six hours prior to the storm. That negative value reduced slowly and returned to the normal variations $12 \mathrm{~h}$ after the storm (Figure 9a). The wind speed was $0.6 \mathrm{~m} / \mathrm{s}$ higher than the mean $18-24 \mathrm{~h}$ prior to the storm, then reduced to $-0.4 \mathrm{~m} / \mathrm{s}$ lower than the mean $10 \mathrm{~h}$ prior to the storm, and returned to the normal variation after the storm (Figure 9d).

When the convective storms occurred in the afternoon, the air temperature did not show an obvious change until several hours prior to the storm, and then dramatically decreased to $-4{ }^{\circ} \mathrm{C}$ (anomaly) during the storm (Figure 9e). The cooling impact quickly reduced, and it returned to the normal variations $12 \mathrm{~h}$ after the storm. Wind speed was $+0.4 \mathrm{~m} / \mathrm{s}$ larger than the mean $6-12 \mathrm{~h}$ prior to the storm, and $-0.4 \mathrm{~m} / \mathrm{s}$ smaller $0-6 \mathrm{~h}$ after the storm (Figure $9 \mathrm{~h}$ ).

When convective storms occurred at night, the impact of the storms on the air temperature and other meteorological factors were reduced compared to the morning and afternoon-occurring storms (Figure 9i-1). The air temperature was $+2{ }^{\circ} \mathrm{C}$ higher than the diurnal mean about $10 \mathrm{~h}$ prior to the storm, and then decreased to $-2{ }^{\circ} \mathrm{C}$ (anomaly) during the storm (Figure 9i). The cooling impact lasted $12 \mathrm{~h}$ after the storm.
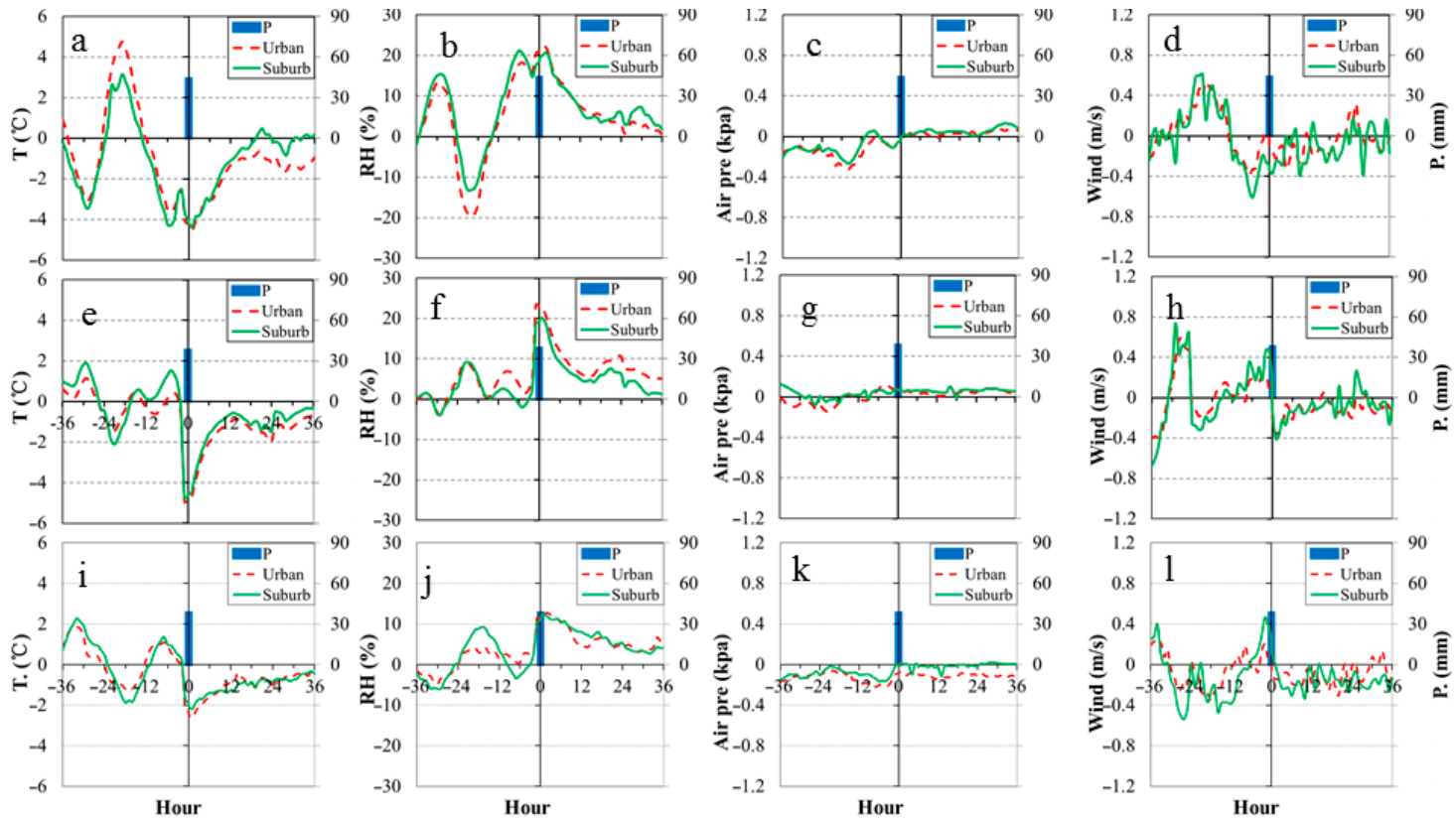

Figure 9. Anomalies of air temperature, relative humidity, surface pressure, and wind speed $36 \mathrm{~h}$ prior to, and after the convective storms that occurred in the morning (8:00-12:00; a-d), afternoon (13:00-18:00; e-h), and night (19:00-7:00; i-1). The references are the diurnal mean during a two-week period centered at but excluding the $72 \mathrm{~h}$ of the storm period from July 2015 to October 2017. The precipitation in the right-hand axis is the mean event-total rainfall.

\subsubsection{Typhoon Storms (July to September)}

Tropical cyclones are rapidly rotating storm systems featuring a low-pressure center, a closed low-level atmospheric circulation, strong winds, spiraling storms, and heavy rain. They are called typhoons in the northwestern Pacific Ocean and hurricanes in the Atlantic Ocean and northeastern Pacific Ocean. Most tropical cyclones that made landfall in South China were formed in the South China Sea and Philippine Sea in the northwestern Pacific Ocean, and the winds blew counterclockwise. There were 2.8 landfall typhoons on average in South China during 1957-1996, contributing 20\%-30\% to the annual rainfall [49]. 
Typhoon storms are mesoscale weather systems (Figure 5i,j). They were accurately identified and consisted $8 \%$ of all storms in the three years examined (Table 3). They occurred evenly within the three periods, with no obvious difference between the urban and suburban stations. Meteorological factor variations were illustrated as an example during the Typhoon Nida, which made landfall in the east of Shenzhen at 04:00 on 2 August 2016 (Figure 6q-t). The surface pressure declined to $98 \mathrm{kPa}$, and the hourly mean wind speed rose to $3 \mathrm{~m} / \mathrm{s}$ during landfall at Tianhe in Guangzhou. The air temperature was more than $6{ }^{\circ} \mathrm{C}$ lower than the diurnal mean $12 \mathrm{~h}$ prior to landfall, and the cooling impact lasted three days after the landfall. It brought $100-200 \mathrm{~mm}$ rainfall in Guangzhou, and the peak rain intensity was $90 \mathrm{~mm} / \mathrm{h} 24 \mathrm{~h}$ after the landfall.

Generally, heavy storms are developed by different weather systems each season, and have unique and dynamically environment structures largely controlled by the three-dimensional air temperature, humidity, pressure, and wind (Figures 5 and 6). Prior to and after a storm, there is usually overcast clouds, which scatters back the shortwave solar radiation and blocks in the Earth's surface long wave radiation. It disturbs the normal diurnal variation of the meteorological factors, thus heavy storms had different impact on meteorological factors when they occurred in the morning, afternoon, and night (Figures 8-10). Meanwhile, in the formation of clouds and storms, the condensation of water vapor releases a large latent energy into atmosphere, resulting in an abnormal rise of air temperature. Subsequently, the rainfall brings down cool water, and the evaporation of the surface rain water absorbs the heat, resulting in a cooling effect on both the Earth's surface and on the lower atmosphere [23]. Thus, the air temperature could rise several degrees above the normal range during the $24 \mathrm{~h}$ prior to the storms, and immediately dropped several degrees below the normal range during and after the storm, resulting in an approximately $6-10^{\circ} \mathrm{C}$ air temperature difference before and during the storms (Figures 6-9, Table 4). The 24-h mean air temperature prior to the storms could be a better indicator for computing the scaling rates of the precipitation extremes with the surface air temperature.

Table 4. Mean air temperature $\left(\mathrm{T} .={ }^{\circ} \mathrm{C}\right) 24 \mathrm{~h}$ prior to the storms and during the storms, and the break air temperature of the scaling rates using the 24-h mean and natural daily mean temperature at the 42 automatic weather stations from July 2015 to October 2017. *All storms only include the three types of storms.

\begin{tabular}{lccccc}
\hline Storms & $\begin{array}{c}\text { 24 h Mean T. } \\
\text { Prior to Rain }\end{array}$ & $\begin{array}{c}\text { Mean T. in } \\
\text { Rain Hours }\end{array}$ & $\begin{array}{c}\text { T. } \\
\text { Difference }\end{array}$ & $\begin{array}{c}\text { Break T. 24 h } \\
\text { Mean }\end{array}$ & $\begin{array}{c}\text { Break T. Daily } \\
\text { Mean }\end{array}$ \\
\hline *All Three & 32.5 & 23.9 & 8.6 & 28 & 26 \\
Cold-front & 31.4 & 22.9 & 8.5 & 28 & 24 \\
Monsoon & 31.9 & 25.3 & 6.7 & 28 & 28 \\
Convective & 32.7 & 25.8 & 7.0 & 28 & 26 \\
\hline
\end{tabular}

\subsection{Scaling Rates}

When all of the storms were considered except for the warm-front and typhoon storms, it showed a peak-like scaling with a break temperature of $28^{\circ} \mathrm{C}$ and a peak precipitation intensity of $67 \mathrm{~mm} / \mathrm{h}$ in the 99th percentile (Figure 10a). The hourly precipitation extremes in the 75th and 99th percentiles increased at a close-CC rate $\left(\sim 7 \%{ }^{\circ} \mathrm{C}^{-1}\right)$, with air temperature below $28^{\circ} \mathrm{C}$, while a negative scaling existed when it was above $28^{\circ} \mathrm{C}$ (Figure 10a). The break temperature was $26^{\circ} \mathrm{C}$ in the 75 th percentile for the cold-front and monsoon storms. The scaling rate of the cold-front storms was overall similar to that of all of the storms, but with a smaller peak intensity of $57 \mathrm{~mm} / \mathrm{h}$ in the 99th percentile (Figure 10b). It displayed a super CC rate for monsoon and convective storms when the 24-h mean air temperature was below $28^{\circ} \mathrm{C}$ and a negative scaling rate when it was above $28^{\circ} \mathrm{C}$ (Figure 10c,d). Their 24-h mean air temperature varied from $24{ }^{\circ} \mathrm{C}$ to $34^{\circ} \mathrm{C}$ prior to the storm. The hourly peak precipitation intensities in the 99 th were 57,71 , and $69 \mathrm{~mm} / \mathrm{h}$ for the cold-front, monsoon, and convective storms, respectively. Meanwhile, the scaling rates were generally similar for the precipitation extremes at the urban and suburban stations (Figure 10e,f). 

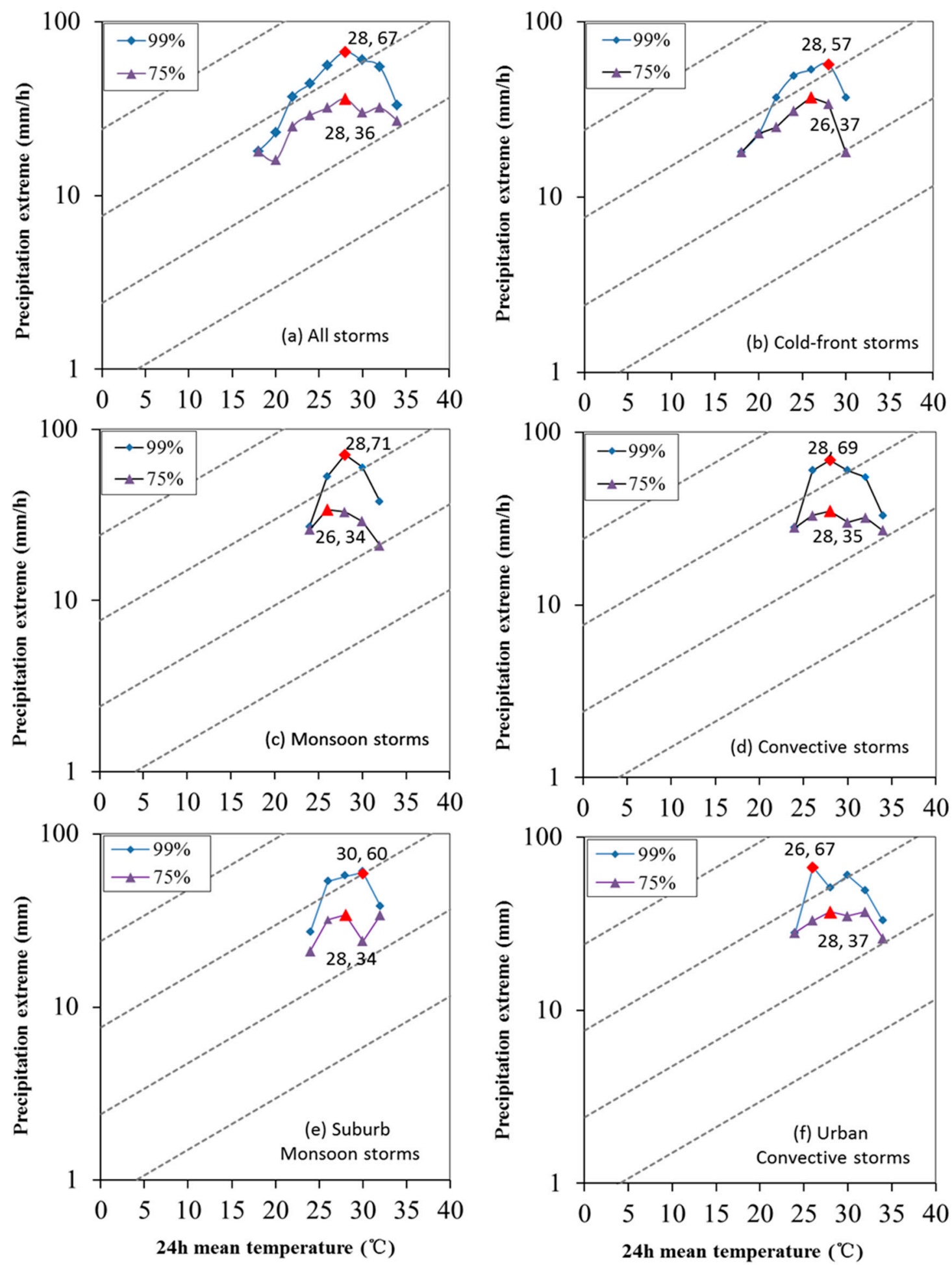

Figure 10. The scaling rates between the 24-h mean air temperature prior to the storms and the hourly precipitation extremes at the 75th and 99th percentile for (a) all of the storms from April to September, (b) cold-front storms from April to mid-May, (c) monsoon storms from mid-May to June, (d) the convective storms from July to September, (e) monsoon storms at the suburb stations, and (f) convective storms at the urban stations. The marked values on each plot are the break temperature and precipitation extremes. The gray dashed lines are the standard Clausius-Clapeyron (CC) scaling rate. The Y-axis scale is in logarithm. 
In contrast, when using the natural daily mean air temperature as in literature, the peak-like scaling structure almost disappeared and only the negative scaling existed, especially in the 75th percentile for the monsoon storms (Figure 11c). The break air temperature dropped to $24^{\circ} \mathrm{C}$ and $26{ }^{\circ} \mathrm{C}$ for the cold-front and convective storms, resulting in a break air temperature of $26{ }^{\circ} \mathrm{C}$ for all three types of storms. A negative scaling rate existed for most of the convective storms (Figure 11d). When the urban and suburban stations were separated, a negative CC scaling rate appeared for the cold-front storms at the suburban stations (Figure 11e) and for convective storms at the urban stations (Figure 11f). Meanwhile, the peak-like scaling structure still existed and was similar at the urban and suburban stations for both the monsoon and convective storms when the 24-h mean air temperature prior to the storms was used in computing the scaling rates (Figure 10e,f). On the one hand, although the air temperature affects extreme precipitation, the atmospheric conditions and precipitation affect the surface air temperature as well. The cooling effect of the storms on the air temperature disturbs the scaling rate between the precipitation extremes and the air temperature. A lower temperature during the storms is widely related to the local saturated downdraughts, rain evaporative cooling, and the synoptic atmospheric properties of colder air in low-pressure systems [23]. This indicates that the 24-h mean air temperature could produce more reliable scaling rates than the naturally daily mean air temperature used in literature.

The peak-like structure of the scaling rates between the precipitation extremes and air temperature revealed in this study are similar to those reported in the literature $[13,14,16,17]$, but are slightly different from those who found negative scaling rates in the tropic and subtropical regions when daily mean air temperature was above $25^{\circ} \mathrm{C}$, such as in Brazil [15], Northern Australia [19], Southern China [20], and Hong Kong [24]. Such negative scaling rates were also identified by using the daily mean temperature for the cold-front and convective storms (Figure 11e,f). Using the 24-h mean air temperature prior to the storms, this study presents a break temperature of $28^{\circ} \mathrm{C}$, above which there was a negative scaling rate for the warm season storms. Figures 6-9 demonstrate that the air temperature normally increased by several degrees $4-24 \mathrm{~h}$ prior to the storm, while it decreased by several degrees immediately during the storm. The transient cooling effect of the tropical storms could be up to $4{ }^{\circ} \mathrm{C}$ in Northern Australia [23]. Table 4 shows that the 24-h mean air temperature prior to the storms was about $7-8{ }^{\circ} \mathrm{C}$ higher than that during the rain hours. This suggests that the 24 -h mean air temperature prior to the storms could be a better indicator than the natural daily mean air temperature in the scaling rate computation, especially for the sub-tropic and tropic storms $[15,23,24]$.

The break air temperature acts like an atmospheric threshold of water vapor availability in the subtropical Guangzhou. The values of the mean temperature $24 \mathrm{~h}$ prior to the storms were 31.4, 31.9 , and $32.7^{\circ} \mathrm{C}$ for the cold-front, monsoon, and convective storms, respectively, and their mean temperatures during the rain hours were $22.9,25.3$, and $25.8^{\circ} \mathrm{C}$ (Table 4). Although both the 24-h and rain-hour mean air temperature were different for the cold-front, monsoon, and convective storms, they all showed a similar break temperature of $28^{\circ} \mathrm{C}$ in the 99th percentile (Figure 10). This was $4{ }^{\circ} \mathrm{C}$ lower than the 24-h mean air temperature prior to the storms and $2-5^{\circ} \mathrm{C}$ higher than those during the rain hours. When the 24-h mean air temperature was lower than $28{ }^{\circ} \mathrm{C}$, the relative humidity was $80 \%-100 \%$, and showed positive scaling rates (Figures 6-10). In contrast, when it was higher than $28^{\circ} \mathrm{C}$, the relative humidity and precipitation extremes had a negative relationship with the air temperature (Figure 12). This further confirms a previous explanation that the negative scaling rates were mainly caused by a lack of moisture $[15,20]$.

The primary mechanism of moisture lack for the high temperature range is likely caused by the delay of evapotranspiration following the rapid increase of air temperature, rather than by the absolute lack of water resource, especially in the humid subtropical area of Guangzhou. As the air temperature rises above $28{ }^{\circ} \mathrm{C}$, the atmosphere is more dynamic. A further rising temperature is potentially associated with different synoptic systems, atmospheric circulation, and moisture advection, thus resulting in different meteorological or precipitation regimes [19,50]. Meanwhile, the spatial variability of the mean air temperature is much smaller than the precipitation extreme, and it might contribute 
to the negative scaling rates when the scaling rates were computed using all of the precipitation extremes at each of the weather stations [14-17]. In other words, such negative scaling rates might be partially related to the analytical method [51], such as those showed in Figures 10 and 11. They showed some positive scaling rates in the tropical regions of Australia, by conditioning the precipitation intensity and storm duration. Nevertheless, given enough time and moisture sources, the scaling rate is still appropriate to project the future rainfall extremes in the context of climate change and global warming $[17,23]$.
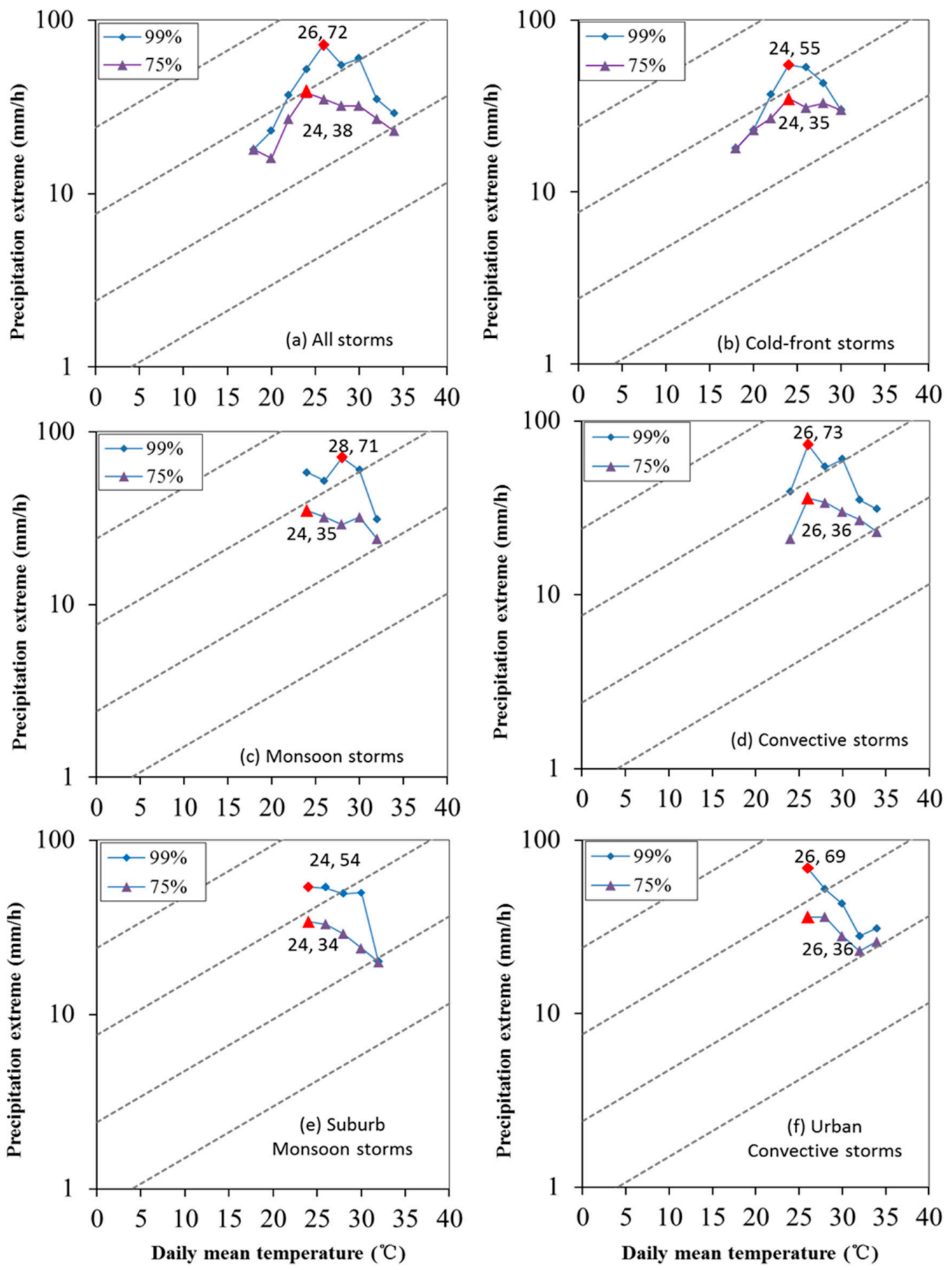

Figure 11. The same as Figure 10, but using the natural daily mean air temperature. 

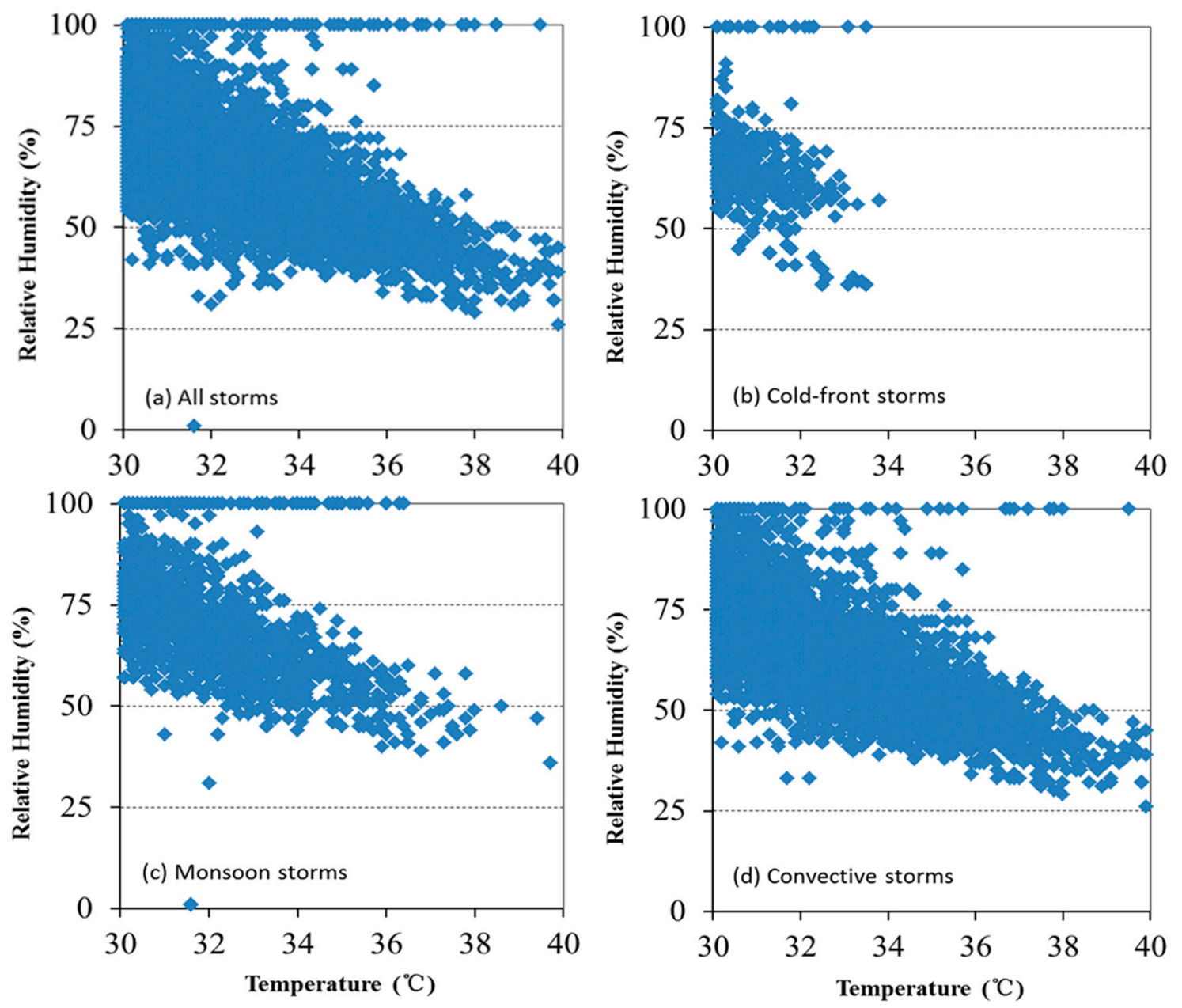

Figure 12. The scatter plots between the relative humidity (\%) and hourly mean air temperature during the periods prior to the storms for (a) all of the storms from April to September, (b) cold-front storms from April to mid-May, (c) monsoon storms from late May to June, and (d) the convective storms from July to September.

\section{Summary and Remark}

There is an ongoing debate on the negative scaling rates between precipitation extremes and surface air temperature in tropic and subtropic regions. A lack of moisture resource was mainly applied to explain the negative scaling rates. However, heavy storms are developed by different weather systems each season in the Southern China. They have complicated interactions with meteorological factors and are the driving force of urban pluvial flooding. This study analyzes the characteristics of heavy storms in the administration areas of Guangzhou, South China, and investigates the variations of meteorological factors with different types of storms, and quantifies the scaling rates between the hourly precipitation extremes with the surface air temperature (i.e., the naturally daily mean temperature and the 24-h mean values prior to the storms).

Except for the warm-front and typhoon storms, the warm season storms have a short duration and intense rates in Guangzhou. Half of the storms had rain duration shorter than three hours, a quarter were in the range of three to five hours, and another quarter were longer than five hours, respectively. The convective storms were dominant by $50 \%$ in urban, followed by monsoon storms and cold-front storms. Urban and suburban areas had different storm hyetographs.

The air temperature showed a different magnitude of fluctuations prior to and after the different types of storms, while the storm types had little influence on the scaling rates between the precipitation extremes and the temperature. Air temperature is one of the leading meteorological factors that 
interacts with heavy storms. It could rise by $6{ }^{\circ} \mathrm{C}$ and drop by $4{ }^{\circ} \mathrm{C}$ prior to and after summer storms. The precipitation extremes showed peak-like scaling rates with the 24-h mean air temperature prior to the storms. For the cold-front, monsoon, and convective storms, they all showed the same break temperature of $28^{\circ} \mathrm{C}$ in the 99 th percentile, which was $4{ }^{\circ} \mathrm{C}$ lower than the 24-h mean air temperature prior to the storms and $2-5^{\circ} \mathrm{C}$ higher than those during the storms. Below $28^{\circ} \mathrm{C}$, the relative humidity was $80 \%-100 \%$, and it showed a positive scaling. In contrast, above $28{ }^{\circ} \mathrm{C}$, the relative humidity decreased with the air temperature increase, which suggests that the negative scaling rates were likely caused by lack of moisture in the atmosphere, instead of by the atmospheric water vapor-holding capacity. Meanwhile, when using the natural daily mean air temperature as in the literature, a lower break temperature appeared for all of the summer storms, partially due to the transient cooling effect, and even purely negative scaling rates appeared for the monsoon storms at the suburban stations and the convective storms at the urban stations. This suggests that the 24-h mean air temperature could be a better variable to use for compute scaling rates rather than the naturally daily mean air temperature.

The storm process-based analysis reveals detailed variations of the meteorological factors prior to, during, and after the storms, especially for the cold-front, monsoon, and convective storms. For large scale storms, such as the winter warm-front storms and typhoon storms, it is limited to analyzing the interactions between the storms and the meteorological factors by using the local weather observations. Fine atmospheric models are needed in order to investigate their full interactions and feedbacks. The accurate forecasting of localized heavy storms is still a sever challenge in present-day climate and weather forecasting models. This study paves a path towards a greater storm-process understanding of the scaling relation between precipitation extreme and air temperature, and offers some suggestions to the forecast of local heavy storms and the urban drainage management in the Southern China.

Author Contributions: Conceptualization, X.W.; methodology, C.P. and X.W.; software, X.W.; validation, D.W. and H.H.; formal analysis, X.W. and C.P.; investigation, C.P., X.W., and H.H.; resources, L.L. and X.W.; data curation, C.P. and D.W.; writing (original draft preparation), C.P. and X.W.; writing (review and editing), L.L. and X.W.; visualization, C.P.; supervision, L.L. and X.W.; project administration, X.W. and L.L.; funding acquisition, X.W.

Funding: This study is funded by the National Natural Science Foundation of China (\#41871085) and the Water Resource Science and Technology Innovation Program of Guangdong Province (\#2016-19).

Acknowledgments: We thank all of the researchers and staff for providing and maintaining the meteorological data in Guangdong and the CMPA data from all agencies. The comments and suggestions from two anonymous reviewers greatly improved this manuscript and are highly appreciated by the authors.

Conflicts of Interest: The authors declare no conflict of interest. The founding sponsors had no role in the design of the study; in the collection, analyses, or interpretation of data; in the writing of the manuscript; and in the decision to publish the results

\section{References}

1. Yang, L.; Tian, F.; Smith, J.A.; Hu, H. Urban signatures in the spatial clustering of summer heavy rainfall events over the Beijing metropolitan region. J. Geophys. Res. Atmos. 2014, 119, 1203-1217. [CrossRef]

2. Liu, L.; Liu, Y.; Wang, X.; Yu, D.; Liu, K.; Huang, H.; Hu, G. Developing an effective 2-D urban flood inundation model for city emergency management based on cellular automata. Nat. Hazards Earth Syst. 2015, 15, 381-391. [CrossRef]

3. Shastri, H.; Paul, S.; Ghosh, S.; Karmakar, S. Impacts of urbanization on Indian summer monsoon rainfall extremes. J. Geophys. Res. Atmos. 2015, 120, 495-516. [CrossRef]

4. Yang, L.; Scheffran, J.; Qin, H.; You, Q. Climate-related flood risks and urban responses in the Pearl River Delta, China. Reg. Environ. Chang. 2015, 15, 379-391. [CrossRef]

5. Pan, C.; Wang, X.; Liu, L.; Huang, H.; Wang, D. Improvement to the Huff Curve for Design Storms and Urban Flooding Simulations in Guangzhou, China. Water 2017, 9, 411. [CrossRef]

6. Shepherd, J.M. A Review of Current Investigations of Urban-Induced Rainfall and Recommendations for the Future. Earth. Interact. 2005, 9, 1-27. [CrossRef]

7. Shem, W.; Shepherd, M. On the impact of urbanization on summertime thunderstorms in Atlanta: Two numerical model case studies. Atmos. Res. 2009, 92, 172-189. [CrossRef] 
8. Pathirana, A.; Denekew, H.B.; Veerbeek, W.; Zevenbergen, C.; Banda, A.T. Impact of urban growth-driven landuse change on microclimate and extreme precipitation-A sensitivity study. Atmos. Res. 2014, 138, 59-72. [CrossRef]

9. Zheng, B.; Gu, D.; Li, C.; Lin, A.; Liang, J. Frontal Rain and Summer Monsoon Rain during Pre-rainy Season in South China. Part II: Spatial Patterns. Chin. J. Atmos. Sci. 2007, 31, 495-504. (In Chinese) [CrossRef]

10. Zheng, B.; Liang, J.; Lin, A.; Li, C.; Gu, D. Frontal Rain and Summer Monsoon Rain During Pre-rainy Season in South China. Part I: Determination of the Division Dates. Chin. J. Atmos. Sci. 2006, 30, 1207-1216. (In Chinese) [CrossRef]

11. Wang, D.S.; Wang, X.; Liu, L.; Wang, D.; Huang, H.; Pan, C. Evaluation of CMPA precipitation estimate in the evolution of typhoon-related storm rainfall in Guangdong, China. J. Hydroinform. 2016, 18, 1464-7141. [CrossRef]

12. Lenderink, G.; van Meijgaard, E. Increase in hourly precipitation extremes beyond expectations from temperature changes. Nat. Geosci. 2008, 1, 511-514. [CrossRef]

13. Drobinski, P.; Alonzo, B.; Bastin, S.; Silva, N.D.; Muller, C. Scaling of precipitation extremes with temperature in the French Mediterranean region: What explains the hook shape? J. Geophys. Res. Atmos. 2016, 121, 3100-3119. [CrossRef]

14. Utsumi, N.; Seto, S.; Kanae, S.; Maeda, E.E.; Oki, T. Does higher surface temperature intensify extreme precipitation? Geophys. Res. Lett. 2011, 38, 239-255. [CrossRef]

15. Maeda, E.E.; Utsumi, N.; Oki, T. Decreasing precipitation extremes at higher temperatures in tropical regions. Nat. Hazards 2012, 64, 935-941. [CrossRef]

16. Panthou, G.; Mailhot, A.; Laurence, E.; Talbot, G. Relationship between Surface Temperature and Extreme Rainfalls: A Multi-Time-Scale and Event-Based Analysis. J. Hydrol. 2014, 15, 1999-2011. [CrossRef]

17. Wang, G.; Wang, D.; Trenberth, K.E.; Erfanian, A.; Yu, M.; Bosilovich, M.G.; Parr, D.T. The peak structure and future changes of the relationships between extreme precipitation and temperature. Nat. Clim. Chang. 2017, 7, 268-274. [CrossRef]

18. Berg, P.; Haerter, J.O. Unexpected increase in precipitation intensity with temperature-A result of mixing of precipitation types? Atmos. Res. 2013, 119, 56-61. [CrossRef]

19. Hardwick Jones, R.; Westra, S.; Sharma, A. Observed relationships between extreme sub-daily precipitation, surface temperature, and relative humidity. Geophys. Res. Lett. 2010, 37, 1-5. [CrossRef]

20. Sun, W.; Li, J.; Yu, R. Corresponding Relation between Warm Season Precipitation Extremes and Surface Air Temperature in South China. Adv. Clim. Chang. Res. 2013, 4, 160-165. [CrossRef]

21. Wasko, C.; Parinussa, R.M.; Sharma, A. A quasi-global assessment of changes in remotely sensed rainfall extremes with temperature. Geophys. Res. Lett. 2016, 4324, 12659-12668. [CrossRef]

22. Ali, H.; Fowler, H.J.; Mishra, V. Global Observational Evidence of Strong Linkage Between Dew Point Temperature and Precipitation Extremes. Geophys. Res. Lett. 2018, 45, 320-330. [CrossRef]

23. Bao, J.; Sherwood, S.C.; Alexander, L.V.; Evans, J.P. Future increases in extreme precipitation exceed observed scaling rates. Nat. Clim. Chang. 2017, 7, 128-132. [CrossRef]

24. Lenderink, G.; Mok, H.Y.; Lee, T.C.; van Oldenborgh, G.J. Scaling and trends of hourly precipitation extremes in two different climate zones-Hong Kong and the Netherlands. Hydrol. Earth Syst. Sci. 2011, 15, 3033-3041. [CrossRef]

25. Ali, H.; Mishra, V. Contrasting response of rainfall extremes to increase in surface air and dewpoint temperatures at urban locations in India. Sci. Rep. 2017, 7, 1228. [CrossRef] [PubMed]

26. Barbero, R.; Westra, S.; Lenderink, G.; Fowler, H.J. Temperature-extreme precipitation scaling: A two-way causality? Int. J. Climatol. 2017, 38, e1274-e1279. [CrossRef]

27. Chen, D.; Chen, H.W. Using the Köppen classification to quantify climate variation and change: An example for 1901-2010. Environ. Dev. 2013, 6, 69-79. [CrossRef]

28. Liu, T.; Zhang, Y.H.; Xu, Y.J.; Lin, H.L.; Xu, X.J.; Luo, Y.; Xiao, J.; Zeng, W.L.; Zhang, W.F.; Chu, C.; et al. The effects of dust-haze on mortality are modified by seasons and individual characteristics in Guangzhou, China. Environ. Pollut. 2014, 187, 116-123. [CrossRef] [PubMed]

29. Xie, L.; Wei, G.; Deng, W.; Zhao, X. Daily $\delta^{18} \mathrm{O}$ and $\delta \mathrm{D}$ of precipitations from 2007 to 2009 in Guangzhou, South China: Implications for changes of moisture sources. J. Hydrol. 2011, 400, 477-489. [CrossRef]

30. Qin, S.; Chao, F.; Lu, R. Large-scale Circulation Anomalies Associated with Interannual Variation in Monthly Rainfall over South China from May to August. Adv. Atmos. Sci. 2014, 31, 273-282. [CrossRef] 
31. Qin, W.; Sun, Z.; Ding, B.; Zhang, A. Precipitation and circulation features during late-spring to early-summer flood rain in South China. J. Nanjing Inst. Meteorol. 1994, 17, 455-461. (In Chinese)

32. Chen, L.; Li, W.; Zhao, P.; Tao, S. On the process of summer monsoon onset over East Asia. Acta Meteorol. Sin. 2001, 5, 345-355. [CrossRef]

33. Lee, M.; Ho, C.; Kim, J. Influence of Tropical Cyclone Landfalls on Spatiotemporal Variations in Typhoon Season Rainfall over South China. Adv. Atmos. Sci. 2010, 27, 443-454. [CrossRef]

34. Ren, F.; Gleason, B.; Easterling, D. Typhoon Impacts on China's Precipitation during 1957-1996. Adv. Atmos. Sci. 2002, 19, 943-952.

35. Costa, A.C.; Soares, A. Homogenization of climate data: review and new perspectives using geostatistics. Math. Geosci. 2009, 413, 291-305. [CrossRef]

36. Xu, W.; Li, Q.; Wang, X.L.; Yang, S.; Cao, L.; Feng, Y. Homogenization of Chinese daily surface air temperatures and analysis of trends in the extreme temperature indices. J. Geophys. Res. Atmos. 2013, 118, 9708-9720. [CrossRef]

37. Gentilucci, M.; Barbieri, M.; Burt, P.; D'Aprile, F. Preliminary Data Validation and Reconstruction of Temperature and Precipitation in Central Italy. Geosciences 2018, 8, 202. [CrossRef]

38. Shen, Y.; Zhao, P.; Pan, Y.; Yu, J. A high spatiotemporal gauge-satellite merged precipitation analysis over China. J. Geophys. Res. Atmos. 2014, 119, 3063-3075. [CrossRef]

39. Wang, D.S.; Wang, X.; Liu, L.; Wang, D.G.; Liang, X.; Pan, C.; Huang, H. Comprehensive evaluation of TMPA 3B42V7, GPM IMERG and CMPA precipitation estimates in Guangdong Province, China. Int. J. Climatol. 2018, 1-18. [CrossRef]

40. Kottegoda, N.T.; Natale, L.; Raiteri, E. Monte Carlo Simulation of rainfall hyetographs for analysis and design. J. Hydrol. 2014, 519, 1-11. [CrossRef]

41. Azli, M.; Rao, A.R. Development of Huff curves for Peninsular Malaysia. J. Hydrol. 2010, 388, 77-84. [CrossRef]

42. Hartigan, J.; Wong, M. Algorithm AS 136: A k-means clustering algorithm. Appl. Stat. 1979, 28, 100-108. [CrossRef]

43. Bonta, J.V.; Rao, A.R. Fitting equations to families of dimensionless cumulative hyetographs. Trans. ASAE 1988, 31, 756-760. [CrossRef]

44. Terranova, O.G.; Gariano, S.L. Rainstorms able to induce flash floods in a Mediterranean-climate region (Calabria, southern Italy). Nat. Hazards Earth Syst. 2014, 14, 2423-2434. [CrossRef]

45. Todisco, F. The internal structure of erosive and non-erosive storm events for interpretation of erosive processes and rainfall simulation. J. Hydrol. 2014, 519, 3651-3663. [CrossRef]

46. Yin, S.Q.; Xie, Y.; Nearing, M.A.; Guo, W.L.; Zhu, Z.Y. Intra-Storm Temporal Patterns of Rainfall in China Using Huff Curves. Trans. ASAE 2016, 59, 1619-1632. [CrossRef]

47. Fadhel, S.; Rico-Ramirez, M.A.; Han, D. Sensitivity of peak flow to the change of rainfall temporal pattern due to warmer climate. J. Hydrol. 2018, 560, 546-559. [CrossRef]

48. Hettiarachchi, S.; Wasko, C.; Sharma, A. Increase in flood risk resulting from climate change in a developed urban watershed-The role of storm temporal patterns. Hydrol. Earth Syst. Sci. 2018, 22, 2041-2056. [CrossRef]

49. Ren, F.; Wu, G.; Dong, W.; Wang, X.; Wang, Y.; Ai, W.; Li, W. Changes in tropical cyclone precipitation over China. Geophys. Res. Lett. 2006, 33, 131-145. [CrossRef]

50. Blenkinsop, S.; Chan, S.C.; Kendon, E.J.; Roberts, N.M.; Fowler, H.J. Temperature influences on intense UK hourly precipitation and dependency on large-scale circulation. Environ. Res. Lett. 2015, 10, 054021. [CrossRef]

51. Wasko, C.; Sharma, A.; Johnson, F. Does storm duration modulate the extreme precipitation-temperature scaling relationship? Geophys. Res. Lett. 2015, 42, 8783-8790. [CrossRef]

(C) 2019 by the authors. Licensee MDPI, Basel, Switzerland. This article is an open access article distributed under the terms and conditions of the Creative Commons Attribution (CC BY) license (http://creativecommons.org/licenses/by/4.0/). 